Collins P.E.F., Worsley P., Keith-Lucas D.M. and Fenwick I.M. 2006. Floodplain environmental change during the Younger Dryas and Holocene: evidence from the lower Kennet Valley, south central England. Palaeogeography, Palaeoclimatology, Palaeoecology 233, 113-133. doi:10.1016/j.palaeo.2005.09.014. 
Collins et al. Kennet Floodplain

\title{
Floodplain environmental change during the Younger Dryas and Holocene in Northwest Europe: insights from the lower Kennet Valley, south central England.
}

\author{
Philip E.F. Collins ${ }^{1 *}$, Peter Worsley ${ }^{2}$, D. Michael KeIth-LuCAS ${ }^{3}$, And IAN M. FenWICK ${ }^{4}$
}

\begin{abstract}
Many lowland rivers across northwest Europe exhibit broadly similar behavioural responses to glacialinterglacial transitions and landscape development. Difficulties exist in assessing these, largely because the evidence from many rivers remains limited and fragmentary. Here we address this issue in the context of the river Kennet, a tributary of the Thames, since c. 13,000 cal. BP). Some similarities with other rivers are present, suggesting that regional climatic shifts are important controls. The Kennet differs from the regional pattern in a number of ways. The rate of response to sudden climatic change, particularly at the start of the Holocene and also mid-Holocene forest clearance, appears very high. This may reflect abrupt shifts between two catchment scale hydrological states arising from contemporary climates, land use change and geology. Stadial hydrology is dominated by nival regimes, with limited winter infiltration and high spring and summer runoff. Under an interglacial climate, infiltration is more significant. The probable absence of permafrost in the catchment means that a lag between the two states due to its gradual decay is unlikely. Palaeoecology, supported by radiocarbon dates, suggests that, at the very start of the Holocene, a dramatic episode of fine sediment deposition across most of the valley floor occurred, lasting 500-1000 years. A phase of peat accumulation followed as mineral sediment supply declined. A further shift led to tufa deposition, initially in small pools, then across the whole floodplain area, with the river flowing through channels cut in tufa and experiencing repeated avulsion. Major floods, leaving large gravel bars that still form positive relief features on the floodplain, followed mid-Holocene floodplain stability. Prehistoric deforestation is likely to be the cause of this flooding, inducing a major environmental shift with significantly increased surface runoff. Since the Bronze Age, predominantly fine sediments were deposited along the valley with apparently stable channels and vertical floodplain accretion associated with soil erosion and less catastrophic flooding. The Kennet demonstrates that, while a general pattern of river behaviour over time, within a region, may be identifiable, individual rivers are
\end{abstract}


Collins et al. Holocene Kennet

likely to diverge from this. Consequently, it is essential to understand catchment controls, particularly the relative significance of surface and subsurface hydrology.

1. Department of Geography \& Earth Sciences, Brunel University, Uxbridge, UB8 3PH, United Kingdom.

2. Oxford University Centre for the Environment, South Parks Road, Oxford OX1 3TB, United Kingdom

3. School of Plant Sciences, University of Reading, Whiteknights, Reading Berkshire RG6 6AS, United Kingdom

4. Department of Geography, University of Reading, Whiteknights, Reading Berkshire RG6 6AB, United Kingdom

${ }^{*}$ Corresponding author: Fax +44 (0) 1895203217

Email: philip.collins@brunel.ac.uk

Keywords: stadial; interglacial; palaeoecology; peat; tufa; flooding

\section{Introduction}

It is now widely accepted that variations in river behaviour in regions with limited tectonic activity is largely a reflection of changes in climatic controls (e.g. Vandenberghe, 1995). In recent years there has been recognition of common intra-regional stages in river response, for example the glacial-interglacial river terrace model (Bridgland and Allen, 1996; Bridgland, 2000), the interglacialglacial fluvial phase model (Gibbard and Lewin, 2002). Present-day river behaviour suggests that, although these models may present the general pattern, individual rivers (and sites) show variability in the rates at which changes occur. This is to some extent reflected in the alluvial assemblage model proposed by Lewin et al. (2005) who suggest a series of episodes represented by preserved sediments.

This paper examines the change in the behaviour of the lower reaches of the river Kennet, south-central England (Figs 1 and 2), and its floodplain for the period commencing with the final stadial of the last (Devensian/Weichselian) cold stage. The Kennet is suitable for such study because of its simple pre-Quaternary geology: Cretaceous chalk in its headwaters and weekly consolidated 
Tertiary sands, silts and clays mainly in its lower reaches. Locally, the Tertiary deposits have been lithified to form sarsen stones. All the Quaternary deposits within the catchment are of local origin, with the exception of a very small number of apparently exotic clasts (Collins, 1994) and some aeolian deposits (Chartres, 1975, 1980, 1981). In contrast to a number of other river catchments across northwest Europe, tectonic activity has been limited. Although isostatic uplift has undoubtedly affected the long-term evolution of the landscape (cf. Bridgland, 2000), no evidence for other significant tectonic influences has yet been identified. In addition, the valley has been the subject of a number of earlier studies which provide additional information extending back to the last cold stage and suggest that, apart from recent human activity, floodplain destruction has been limited.

\subsection{Palaeoclimatic and human context}

The time immediately before and after the last glacial-interglacial transition at circa 11,500 cal. yr BP represents perhaps the most dramatic series of climatic shifts of the last 15,000 years, with high amplitude variability over short intervals (Taylor et al., 1993) and the impact of these has been recognised in a number of continental and marine environmental settings in the North Atlantic region (e.g. Pennington, 1977; Lehman and Keigwin, 1992; Mayle and Cwynar, 1995; Andren et al., 1999; Brauer et al., 1999). In the middle and especially late Holocene, there is growing consensus that human activity has had an increasingly dominant influence on natural systems, though climatic variability can still be recognised at many sites (e.g. Barber et al., 2000).

\section{Study area}

The River Kennet is a west-bank tributary of the Thames (Fig. 2) and flows eastwards from the chalk Downs around Marlborough on to Tertiary strata near Newbury, returning on to Chalk at Reading. The catchment above Theale covers an area of approximately $1040 \mathrm{~km}^{2}$. Sandy gravel, almost entirely of a fluvio-periglacial origin, form Quaternary river terraces on the interfluves and valley sides (Thomas, 1961; Cheetham, 1980; Mathers \& Smith 2000). No unambiguous evidence for any incursions of glacial ice into the catchment is known. In addition to the main river, there are several other channels, many of which are artificial (e.g. those created during canalisation of the Kennet). In some areas of the valley floor, 18th and 19th Century peat extraction has completely removed the natural floodplain, lowering the surface by several metres (Collins, 1994). 
The present hydrology of the Kennet upstream of Woolhampton (Fig. 2) is dominated by groundwater supply from the chalk aquifer (Limbrick et al., 2000). River discharge varies seasonally and between years (Bradford, 2002), reflecting the rapid percolation of water through the chalk. Numerous dry valley systems occur on the chalk suggesting past conditions favoured much higher surface runoff (Cheetham, 1980), though the age of these is not known. Unlike the Upper Thames catchment north of the Kennet (Seddon \& Holyoak, 1985), there is no unambiguous evidence for former permafrost in the catchment. However, infiltration during cold stages is likely to have been significantly reduced through extended seasonal freezing if permafrost was absent.

The present climate is temperate, with precipitation occurring in all months of the year. Winters are cool (January mean temperature is around $4^{\circ} \mathrm{C}$ ) and, when snow does fall, it rarely lies for long periods. Summers are typically mild (July mean temperature is around $19^{\circ} \mathrm{C}$ ), with some of the rainfall occurring during thunderstorms. The 'natural' vegetation is difficult to accurately reconstruct as there has been human activity in the region since the early Holocene (Barton et al., 1998). The available evidence (see below) suggests it would be a mosaic of deciduous woodland types, perhaps with Tilia more significant on chalk areas and Quercus on more acidic substrates. Alnus carr woodland would be expected to occur in damper areas.

Several Late Devensian and Holocene sedimentary sequences have been described from the lower parts of the valley (Fig. 2), often in association with archaeological investigations (e.g. Palmer, 1872-75; Peake, 1922, 1934; Churchill, 1962; Wymer, 1962; Froom, 1963; Sheridan et al., 1967; Cheetham, 1975; Bradley et al., 1980; Butterworth and Lobb, 1992; Holyoak, 1980, 1983; Healy et al., 1992; Barton et al., 1998). The current study is concerned with the upper part of the Heales Lock Member and the overlying Midgham Member, both parts of the Kennet Valley Formation (Collins, 1999), covering the time interval from the onset of the Younger Dryas to the present day (approximately 13,000 to $0 \mathrm{BP}$ ). The sequences all underlie the modern floodplain, which has a surface gradient of approximately $1.5 \mathrm{~m} \mathrm{~km}^{-1}$. The focus is on a site at Woolhampton (Figs $2 \& 3$ ). For clarity in the following commentary the relevant parts of the Heales Lock Member are differentiated from earlier elements as sub-units HLM3 and HLM4 (Fig. 4).

\section{Methods}

\subsection{Morphostratigraphy}


Collins et al. Kennet Floodplain

The morphostratigraphy of sediments in the lower Kennet valley was determined by field geomorphological mapping (Fig. 3), borehole data and multiple quarry and riverbank exposures (Worsley \& Collins 1995). Major lithostratigraphic changes provide the interpretative framework used here (Fig. 4).

\subsection{Sedimentology}

Carbonate material was common throughout the sequence, mainly as soft tufa. Where the carbonate had been deposited as clasts (e.g. as fragmented tufa gravel or reworked tufa nodules) there was often evidence that these had been affected by subsequent dissolution and reprecipitation (such as vertical tufa laminae lining desiccation cracks). Much of the tufa appears to have formed by direct precipitation and hence any measure of the texture of such non-durable material produces inaccurate results. This was demonstrable by the fact that a number of tufa and silt samples lost between $16-65 \%$ of their original dry mass during acid pre-treatment, prior to sieving and sedimentation analyses.

\subsection{Palaeoecology}

Holyoak (1980) and Churchill (1962) provide detailed accounts of the palaeoecology of floodplain deposits at Thatcham (Fig. 2). Data from a number of other sites are given in Cheetham (1975) and Collins (1994). Here we present new information from Woolhampton

Selected samples from quarry exposures at Woolhampton were prepared for pollen analysis by successive treatments of $\mathrm{NaOH}, \mathrm{HCl}, \mathrm{HF}$, glacial acetic acid and acetolysis. Prepared samples were mounted in glycerine jelly with a safranin stain. Pollen and spore types follow Moore et al. (1991), modified to the taxonomic system of Stace (1997) following Bennett et al. (1994). PreQuaternary palynomorphs derived from Tertiary and Cretaceous strata in the catchment were also counted. Relative frequency variations are given in Figs. 5 and 6 . Pollen analytical investigations focused upon individual samples from the Heales Lock Member and two exposures in the Midgham Member (MM\#A and MM\#B - Fig. 3a) that reflected the major lithostratigraphic units at the site. A $1.6 \mathrm{~m}$ difference in the elevation of their bases reflected the original relative geomorphological position of the two exposures, MM\#A (UK Grid reference SU56356632) was on the former floodplain while 
MM\#B (SU56136594) was within a channel. By considering two such positions, local pollen supply and taphonomic effects on the assemblages could more easily be identified.

In several samples, total pollen and spore counts were small as a result of low concentrations in mineral sediment. Therefore, interpretation of the pollen assemblages is based primarily upon the most common taxa. The degree to which a particular assemblage contains reworked Quaternary pollen and spores can be assessed by considering when pre-Quaternary material is being delivered, though an exact correlation cannot be assumed. Pollen preservation was variable, with grains being generally less well preserved in MM\#A than MM\#B.

During analysis of $\mathrm{MM \# B}$, a semi-quantitative assessment of microscopic charred particle content was attempted. This involved counting the number of carbonised fragments present on the pollen slides and expressing their relative frequency in a series of classes between rare to very abundant. Clearly, there are limitations to such an approach, not least if carbonised particle size varies between samples. Nevertheless, the major variations in charred particle frequency shown in Fig. 6 are real.

Molluscan identifications follow Kerney and Cameron (1979) and Ellis (1978). Mr. H. Carter of the Museum of Reading kindly identified the vertebrate remains.

\subsection{Geochronology}

A geochronological framework is provided by a number of carefully assessed radiocarbon age estimates from a series of sites in the lower Kennet between Hungerford and Reading (Fig. 8). Evaluation of radiocarbon data from the last interglacial-glacial transition is problematic because of the variations in atmospheric ${ }^{14} \mathrm{C}$ during that interval. Organic material from fluvial deposits gives rise to difficulties because of the potential for reworking and contamination. The age estimates produced by the radiocarbon method reflect the time when the organism was alive (plus any effects relating to contamination), and not necessarily the true age of the sediment unit from which they are extracted, a point which is sometimes overlooked. In the context of the Kennet, further potential problems include 'hard water effects' where part of the carbon uptake by aquatic plants is derived from 'infinitely old' carbonate rocks in the catchment (in this case Cretaceous chalk) and also varying degrees by bioturbation and pedogenesis that have affected shallower sediments. 
Collins et al. Kennet Floodplain

It is essential that calendar years are considered, where possible, as these: a) are closer to the 'true' age of samples; b) permit better estimates of possible rates of change; and c) allow comparisons with other independent chronologies e.g., ice cores and varves (e.g. Björk et al., 1998). Consequently, all the results have been calibrated using OxCal 3.9 (Bronk Ramsey, 2003) and expressed as two standard deviation range of years before present (cal BP).

To date, it has not proved possible to date precisely every unit in the lower Kennet, particularly carbonate-rich sediments. Where possible, units were correlated with similar sequences elsewhere in the Kennet and beyond, where chronological control was better constrained, using morphostratigraphic, sedimentary, palaeoecological (particularly pollen and plant macrofossils, but also some Mollusca), and in places archaeological characteristics.

\section{Heales Lock Member: upper elements HLM3 and HLM4}

Details of the Heales Lock Member at Woolhampton are given by Collins et al. (1996). Recent exposures have provided new data, in particular in relation to the post-Windermere (Lateglacial) Interstadial subunits (i.e. HLM3 and HLM4), permitting a refinement of the interpretation presented earlier. Additional information is summarised in Collins (1994) and Worsley and Collins (1995).

\subsection{HLM3: gravel}

Subunit HLM3 is identifiable as far upstream as Hungerford and downstream to the KennetThames confluence where it merges with the Shepperton Member (Gibbard, 1999) of the Middle Thames. The base of HLM3 is defined by a significant bounding surface (cf. Miall, 1990), in effect a combination of a paraconformity across the top of the Wasing Bed (HLM2) and earlier gravels (HLM1) and an angular unconformity with the Tertiary London Clay. This appears to represent a phase of mainly lateral erosion.

HLM3 is predominantly composed of stacked poorly sorted sand and gravel units up to $4 \mathrm{~m}$ thick (facies type Gm; Miall, 1977). Very rarely, stratified gravel (facies type Gt) is present. Small beds of fine sediment that sometimes include organic remains occur locally, representing infills of channels and former scour holes. Large clasts occasionally occur within the gravels and are interpreted as resulting from the rafting of blocks of frozen sediment. Some of these clasts are 
composed of unlithified silt but are more frequently orthoquartzites (sarsens) derived from the Tertiary. Such sediments are similar to those being deposited in modern gravel bed braided rivers with highly variable discharge regimes (Smith, 1974; Miall, 1977; Baumgart-Kotarba, 1989).

Organic remains are rare in most of HLM 3, with most of the identifiable macro plant remains being within the uppermost part of the unit (1.0-1.5 $\mathrm{m}$ from the top). The palaeoecological signatures from HLM3 are similar to many cold stage assemblages from southern England (Collins et al., 1996) with no conclusive evidence for woodland in the region. High relative frequencies of reworked PreQuaternary palynomorphs (up to $30 \%$ of the total assemblage) preclude precise interpretations of the Quaternary taxa within the assemblages. Pollen assemblages are dominated by open habitat taxa, with no thermophilous taxa, suggesting that either the Quaternary pollen present was derived from a contemporary community existing under a cold climatic regime, or that the pollen was being reworked from stadial deposits. Betula pollen is present but it proved impossible to determine whether these originated from tree or dwarf birch.

Its stratigraphic position and palaeoecology place HLM3 in the Younger Dryas (Loch Lomond) Stadial. This is supported by radiocarbon results from near the top of the unit which date to the latter part of the stadial (Fig. 8).

\subsection{HLM4: sand and gravel}

Clastic sediments at the top of the Heales Lock Member at Woolhampton can be distinguished from HLM3 by a locally occurring erosive contact. In many sections this HLM3/HLM4 bounding surface was indistinct due to the disturbance to the sediments during stripping of the overburden before quarrying. The thickest elements of this unit were present in exposures running approximately southeast to northwest across the site, probably reflecting the main flow axis (Fig. 3).

HLM4 sediments frequently displayed cross stratification (facies types Gp and Gt). Significantly, in two adjacent quarry sections, distinct channels were recorded (Collins et al., 1996, figure 8). In one, alternating fine gravel, sand and silt lateral accretion units, suggested both a reduction in flow competence and a shift in flow regime. Structureless gravels overlay these wellstratified sediments. The channel fill also provided evidence for post-depositional disturbance of the sediments, most likely resulting from the thawing of buried ice. The second channel was infilled by gravels of facies type $\mathrm{Gm}$ that expressed indistinct bedding structures. 
Collins et al. Kennet Floodplain

At Woolhampton, HLM4 sometimes contained tufa occurring either as tufa coating flint clasts or as distinct oncoliths. Locally, this tufa contained a small number of large, damaged gastropod shells (either Arianta sp. or Cepaea sp. - see Preece, 1998a).

Pollen assemblages from HLM4 were highly variable, partly an artefact of low pollen counts from some samples containing little identifiable pollen, though taphonomic processes may have influenced the composition of the assemblages. Betula and Salix appear to have been present nearby, though the area appears to have been otherwise treeless. There is a high diversity of plant macrofossil, pollen and spore taxa (in total 7 tree/shrub types, 37 herb types, 5 aquatic types, 7 spore types), representing a range of open habitats, including damp meadows and shallow, perhaps ephemeral water bodies and mudflats, together with more permanent ponds.

The palaeoecology of HLM4 is broadly stadial in nature, though some aspects (e.g. the presence of Cepaea/Arianta) may suggest an amelioration of conditions. Radiocarbon dates overlap the Lateglacial/Holocene transition (Fig. 8).

\section{Midgham Member at Woolhampton}

Overlying the Heales Lock Member is the generally fine-textured Midgham Member. This is laterally extensive, with elements identifiable at least as far downstream as Burghfield Mill (SU670707) and upstream to Kintbury (SU380674) and is correlated by Gibbard (1999) with the Staines Member of the Middle Thames.

The Member is internally heterogeneous. On the basis of field observations by the authors extending back over 30 years and reported descriptions (Fig. 7), six main elements can be identified (MM1-6; Fig. 4b). At Woolhampton, two sequences representative of different depositional settings were examined for pollen. MM\#A largely consists of vertically aggraded sediments laid down on a floodplain, while MM\#B includes organic channel-fill deposits (locations on Fig. 3a).

The base of the member is a paraconformity across HLM3 and HLM4, with a relief of up to 2.5 metres, representing the former braidplain surface. This typically corresponds with an abrupt facies change from gravel to sand, silt and clay, although occasionally there is a more gradual transition with gravel beds being replaced by finer sediments.

5.1 MM1: sand, silt and clay 
This basal unit extends under most of the present floodplain, with the exception of where higher palaeobar surfaces of the former braid plain are preserved. It can be traced in quarry exposures and boreholes near Reading westwards to at least Hungerford and may be correlated with a marl and fine gravel unit in the upper Kennet ('Layer 9' of Evans et al., 1993).

Sedimentary structures are restricted to occasional gravel beds, normally a few clasts thick. There is some lateral and vertical variability, though the unit is predominantly fine-grained throughout. At Thatcham, some tufa may belong to this unit, though the relationship is uncertain. The most likely broader environmental interpretation is an aggrading stream overloaded with fine sediments, with possibly several shallow, generally low energy channels migrating or avulsing (cf. Makaske, 2001) across an expanse of mud.

Pollen assemblages from Woolhampton (Figs. 5 and 6) are similar to those extracted from stadial deposits at the site (Collins et al., 1996) and at Thatcham (Holyoak, 1980). MM\#A yielded a large number of Pre-Quaternary palynomorphs, suggesting significant reworking. In contrast MM\#B contained far fewer Pre-Quaternary grains and preservation was generally good. Herbaceous types indicating damp meadow on the floodplain dominated the assemblages. Betula pollen was present, with a few grains appearing morphologically similar to $B$. nana, though this level of identification is tentative. The low relative frequencies imply few, if any birch trees were present on the floodplain at this time. The region appears to have been otherwise treeless.

Macroscopic organic remains are rare and, where present, normally unidentifiable. One sample, which yielded a poorly preserved plant macrofossil assemblage of Drepanocladus fluitans (Hedw.) Warnst., Potamogeton spp. and Carex rostrata L., indicates a community occupying channels partially infilled by fine sediment. Chenopodium sp. seeds were also present, probably representing communities present on slightly higher ground such as inactive bar surfaces, adjacent to the dynamic channels.

A detailed study of the Mollusca is not included here. One sample yielded a limited assemblage dominated by Aegopinella cf. pura and Vallonia pulchella, with rare Cochlocopa lubricella, Aegopinella cf. nitidula and Oxychilus sp. Towards the top of MM1, more thermophilous taxa (e.g. Carychium tridendatum) have been found (Champness, 1999) showing that at least part of the unit post-dates the initiation of the Holocene. 
Collins et al. Kennet Floodplain

The precise timing of deposition of MM1 is difficult to determine at present and it may diachronous. Available radiocarbon dates place it in the first thousand years of the Holocene. Barton et al. (1998) report optically stimulated luminescence dates of 10,250 $\pm 1,100 \mathrm{BP}$ and 13,000 $\pm 1,350$ BP from silty-clay at Avington containing a Final Upper Palaeolithic lithic assemblage but the precision of these dates is not sufficient to allow safe correlation with other sites in the valley.

A sandy channel fill resting on gravels at Thatcham ('Layer 3' of Healey et al., 1992) initially appears similar to MM1 at Woolhampton, though arboreal pollen and a radiocarbon date from hazel shells (BM-2744) suggest this layer accumulated some time later than MM1 at Woolhampton.

Age estimates from sediments below and above the subunit provide the best confining dating control for MM1. At Woolhampton, calibrated ${ }^{14} \mathrm{C}$ dates from HLM4 and an in situ Salix stump on top of MM2 overlap at two standard deviations (Fig. 8). A similar situation occurs at Thatcham (Fig. 8). The implication is that the deposition of fines across much of the floodplain was a short-lived phenomenon occurring at or immediately after the last glacial-interglacial transition, perhaps only lasting a few hundred years.

\subsection{MM2: peat}

MM1 merges upwards into a peat largely composed of humified plant detritus. Preservation is generally poor, with desiccation cracks, root and burrow penetration in places. Better-preserved sequences have been reported at Thatcham by Holyoak $(1980,1983)$ and are present in some sections at Woolhampton. Peat elevation varies, with a higher, thinner element extending across the former floodplain surface (represented in section MM\#A, Fig. 5, and by the 'terrace peat' reported by Churchill, 1962, at Thatcham) and a lower, thicker element infilling palaeochannels (in section MM\#B, Fig. 6). In places, the peat forms only a thin organic veneer across the higher palaeobar surfaces. Occasionally, within the channels, bedded organic detritus indicates low energy conditions. Gravelsized material occurs either as stringers, interpreted as rare flood events, or as isolated clasts possibly due to rafting by floating vegetation.

Pollen was best preserved in MM\#B with only a single assemblage of identifiable grains being extracted from this unit in MM\#A. Pre-Quaternary grains are rare, suggesting only a limited reworked pollen input. Pinus, Betula and Poaceae dominate, indicating woodland with open areas, most probably nearby on the floodplain where there was also some willow carr, an interpretation supported 
by in situ Salix spp. stumps at Woolhampton. The presence of a number of ruderal types (e.g. Matricaria) reflects communities on higher gravel surfaces nearby, and perhaps also grazing.

Quercus and Ulmus appear at very low frequencies halfway up the unit in MM\#B but are absent from MM2 in section MM\#A. Corylus avellana type is present throughout but increases noticeably at the top (careful examination and comparison with type slides showed the grains had a closer affinity to C. avellana than Myrica gale). This is associated with a decrease in the relative frequencies of most other types. An increase in the microscopic charcoal content of the peat in MM\#B also occurs at this level. It may be that Corylus pollen production and delivery was aided by more open woodland conditions, perhaps as a result of natural or deliberately set fire. Charcoal analysis by Champness (1999) suggests repeated fires. Aquatic pollen types indicate slowly flowing water.

A single damaged Pisidium spp. valve was extracted from this unit in MM\#A. The absence of other Mollusca could reflect post-depositional degradation but the presence of only one fragile valve suggests that an original paucity in shells is more probable.

An initial minimum age estimate for MM2 at Woolhampton is provided by a radiocarbon assay from an in situ willow stump on top of the peat and covered by MM4 (Beta-84057). Taken with ages obtained from MM2 elsewhere in the lower Kennet, this suggests a significant phase of organic accumulation across the valley floor between circa 11,000-9,800 cal. yr BP. Pollen assemblage characteristics support this estimate though the accuracy of this chronological control may be affected by local variations in contemporary vegetation composition, and hence pollen supply. The presence of Pinus and Quercus, and the Corylus expansion at Woolhampton and elsewhere in the valley support an early Holocene age. Similar expansion of Corylus has been recorded at other sites in southern England at or following about 10,500 cal BP (e.g. Preece, 1998b).

Two samples from the Thatcham Mesolithic site were attributed to the 'Boreal' substage by Churchill (1962) as, along with unidentified wood fragments, they contained hazel nut fragments. These samples, however, have older apparent ${ }^{14} \mathrm{C}$ ages than other material yet dated from MM2 (Figure 8). They are considerably older than a third sample from the site (BM-2744), which was associated with very similar flint artefacts (Healy et al. 1992). It seems likely that the wood fragments in the samples reported by Churchill (1962) were reworked from an older deposit, or some other contamination occurred. 
Collins et al. Kennet Floodplain

\subsection{MM3: tufa and peat}

The upward transition from MM2 is gradual, with a progressive increase in fine-grained tufa, initially as laminae. In places, these laminae thicken to form distinct units up to $5 \mathrm{~cm}$ thick, which alternate with organic-rich detritus of similar thicknesses. The tufa generally varies from a silt (marl) to a crumbly mass of weak sand-sized aggregates, consistent with formation as a paludal deposit, with calcium carbonate-saturated water entering shallow pools where it precipitates as a mud (Pedley et al., 2003).

The increase in the amount of tufa in the MM3 suggests conditions favourable for the dissolution of large quantities of chalk in the Kennet's upper catchment and its subsequent precipitation on the floodplain. This may reflect the combined effects of reduced surface runoff and increased groundwater supply to the river as a result of interglacial conditions, expanded vegetation cover and associated pedogenic weathering.

The alternating beds of tufa and organic sediments locally present at both Woolhampton and Thatcham (Holyoak, 1980) indicate oscillations in hydrological conditions. Identifiable Mollusca were all small (1-10 mm; dominated by Carychium cf. tridentatum, Vallonia pulchella and Aegopinella cf. pura), though rare fragments of larger shells were present. The aquatic elements indicate a low energy, permanent water body, while the terrestrial Mollusca represent a range of habitats including marsh, grassland and damp deciduous woodland. The ecologically mixed assemblage may be a function of fluctuating water levels, perhaps associated with the development of temporary lakes and ponds following flooding events.

Pollen assemblages from this unit in section MM\#A are similar to those from MM2. Pinus frequencies are highest at the base, with a subsequent decrease in both its local and regional significance. Corylus type becomes increasingly frequent while Betula is virtually absent from the assemblages. Cyperaceae and Poaceae dominate the herbaceous pollen at the top of MM3, indicating wetter floodplain conditions.

Precise time control for MM3 is difficult to achieve. It is possible, and indeed likely, that MM3 is diachronous, within the range of the radiocarbon dates from this unit (Fig. 8). The available dates probably do not reliably reflect this since at least three of the oldest dates are from samples containing abundant arboreal pollen and overlie material with a younger apparent radiocarbon age, suggestive of 
reworking. The remaining dates group around $10,000-8,000$ cal BP. Quercus is present in MM3 at Woolhampton, while Tilia is absent. This implies a date prior to circa 9500 cal BP (cf. Waller 1993; Preece 1998b) but this age estimate must be considered tentative.

\subsection{MM4: granular tufa}

This element normally overlies MM3 conformably across most of the site, though in places it occupies channels and rests directly upon MM2 (Figs $3 \& 4$ ), locally burying in situ Salix stumps. MM4 is granular, with gravel-sized nodules and tubes. The nodules contain clast or shell nuclei while the tubes occasionally contain evidence of the stick, root or bone fragment around which they formed. 'Stromatolite-like' masses and sheets of laminated tufa also occur on former channel margins. This tufa is very similar to that attributed to accumulation in flowing water (Ordóñez \& Garcia del Cura, 1983; Pedley et al., 2003).

Away from the channels, the granular tufa is relatively uniform in thickness. It seems likely that, in addition to the main channel, there may also have been a number of distributaries, perhaps ephemeral in nature, which channelled carbonate-rich water across the floodplain.

Although many of the pollen grains from MM4 were damaged, most could be identified. Pollen from this unit can be divided into two vegetation phases. The earlier was characterised by high Poaceae, Cyperaceae and Corylus type, with lower frequencies of Betula and Filipendula. These may reflect damp meadow and hazel-birch woodland. Deciduous tree types, Quercus, Tilia and UImus occur at low frequencies and seem to have not been a major element of the local vegetation. The upper part of MM4 is characterised by high relative frequencies of Alnus, indicating the expansion of alder-dominated carr woodland on the floodplain, replacing meadow, though sedge communities may have continued to thrive in wetter, more open areas.

Few Mollusca were found in this unit, those present between $0.65-0.7 \mathrm{~m}$ depth in MM\#1 (Aegopinella cf. nitidula, Cochlicopa lubrica/lubricella, Vallonia pulchella, Succinea cf. putris) indicating damp deciduous woodland, grassland, marsh and flowing water. Champness (1999) found an increase in Oxyloma pfeifferi towards the top, as the tufa became more nodular, indicating fasterflowing water.

The top of MM4 at Woolhampton features organic and non-carbonate mineral matter and exhibits a soil-like blocky aggregate structure. Degraded remains of oncoliths occur, also suggesting 
pedogenesis. Branching and sinuous silt filled burrows extend some $10 \mathrm{~cm}$ down from the base of this horizon. One shell of Ceciloides acicula was extracted from this layer. As this is a burrowing species it is possible it is younger than the sediment, though its ecological requirements (Holyoak 1983) are not dissimilar to the other Mollusca in the assemblage which indicate damp woodland and grassland. The two aquatic species from this horizon are noted for drought tolerance (Kerney and Cameron, 1979) and possibly reflect variable flow levels.

Dating MM4 is problematic as no samples suitable for radiocarbon assay have yet been found. Pollen assemblages, particularly with the expansion of Alnus and Tilia, are similar to other deposits in southern Britain that date to after circa 9,500 cal BP (e.g. Day, 1991; Bennett and Preece, 1998). The exact timing of the first expansion of Alnus in southern England is uncertain, though many sites show its expansion by 8,000 cal BP.

\subsection{MM5: tufa and gravel}

A significant bounding surface occurs at the base of MM5, representing a phase of erosion followed by deposition of coarse sediments. This erosion locally removed all the earlier subunits of the Member and, in places, it even incised into the top of the Heales Lock Member. MM5 contains coarse gravel, up to $3 \mathrm{~cm}$ diameter, which is generally encased in tufa, tufa oncoliths and granular tufa. There are also beds consisting almost entirely of shells, mainly allochthonous assemblages of Succinea putris and clasts of peat, silt and tufa identical to material in subunits MM1-4. The subunit is present at Woolhampton as a discontinuous linear feature across the modern floodplain, often present as a rounded ridge (Fig. 3) that represents a sequence of bars formed during a period of floods. The boundaries of the channel within which these bars formed have not been found during over ten years of site monitoring and it seems probable that subsequent processes including peat digging and farming have destroyed them.

A number of bones were present within the unit. Cervus sp. remains were typically poorly preserved and extremely fragile, suggesting they may have been reworked from an older deposit. In comparison, a number of reasonably well preserved bones from a juvenile domesticated cow found in close proximity at SU56156005 within undisturbed current bedded tufa, may have been more or less the same age as the deposit. As much of the unit had clearly been reworked from pre-existing sediments, pollen analysis is problematic. An organic-rich sand clast contained a pollen assemblage 
similar to those from MM3 and the base of MM4. No other samples examined to date have contained sufficient identifiable pollen to provide any useful information.

The age relationship between the uppermost horizon in MM4 and the channel fills represented by MM5 at Woolhampton is not completely clear. The channel features at the base of MM5 may have been functioning whilst the former was developing. Indeed, increased containment of the flow within channels at this time may help to explain why parts of the floodplain appeared to be more stable.

The presence of domesticated cattle bones in MM5 at Woolhampton suggests a Neolithic maximum age. The estimated age of 1,730-1,450 cal. BP (Beta-84058) for a cattle bone implies a much later date. In the context of the likely age of much of MM6 discussed below, however, this single date seems an underestimate and may reflect sample contamination prior to retrieval.

To date, the extent of this flooding in the lower Kennet valley is unknown. Ridges underlain by tufa are present upstream of Newbury (Buckland, 1825; Peake, 1922). In the upper Kennet deposition of an extensive fine-grained calcareous unit (the 'West Overton Formation'; Evans et al., 1993 ) is associated with the Beaker Period and has been dated between 4,650-3,650 cal. BP (OxA1221) and 2,750-2,360 cal. BP (OxA-1046). Gravel within the Formation suggests significantly enhanced runoff, a process that was possibly also partly responsible for the headward extension of the active channel of the Kennet during this interval.

The age for MM5, therefore seems likely to lie sometime between approximately 5,000-2400 cal. BP.

\subsection{MM6: silt/modern soil}

Immediately under the lower Kennet floodplain is a structureless, calcareous silt and sand. The lack of internal structure within the unit is almost certainly due to 'synsedimentary pedogenesis' following deposition on the floodplain surface (Hayward 1985). The floodplain environment has experienced significant modification over the last few centuries, including the construction of channels to supply water mills, partial canalisation of the river, creation of lakes through peat, sand and gravel extraction, and farming. Despite this, many floodplain successions remain intact.

Pollen assemblages from this unit have been significantly affected by pedogenesis producing differential preservation. This is marked by much higher frequencies of Lactuceae than in any other 
Collins et al. Kennet Floodplain

assemblage from the Midgham Member. It is clearly unsound to make any palaeoecological conclusions from these pollen assemblages, beyond noting that Alnus, a normally resistant pollen type, is less frequent, reflecting a decline in alder carr. A limited molluscan survey of this subunit in MM\#A produced a number of shells indicative of damp grassland and wetland vegetation (Aegopinella cf. nitidula, Vallonia costata, V, pulchella. Succinea sp.). Prior to the beginning of quarrying at the site, carr woodland had certainly been replaced by grassland and ash plantations.

Direct dating control for subunit MM6 at Woolhampton is limited. Romano-British and later artefacts were found in MM6 at Woolhampton (Collins, 1994), which indicates that deposition began at least some 2,000 years ago. Similar deposits associated with archaeological finds, occurred at Field Farm (ca SU675704) and Anslow's Cottages, Burghfield (ca SU693710) and demonstrate that silt deposition has occurred between the Bronze Age and the present day (Butterworth \& Lobb, 1992). The unit appears to correlate in part with the West Overton Formation of the upper Kennet though, for much of this time interval, in its upper reaches, the Kennet appears to have had a stable floodplain surface (Evans et al., 1993).

\section{Synchronicity and chronology of response within the lower Kennet Valley}

The Lateglacial and Holocene sediment units defined at Woolhampton can be traced throughout much of the valley (Fig. 7). This indicates widespread phases of stability and episodes of change reflecting catchment-scale controls. There is some variability in age estimates for the same unit at different sites, though the precision of the radiocarbon and pollen-based chronology for the lower Kennet is not sufficient to determine exactly how synchronous the changes were but the temporal clustering of dates within units implies short-lived phases that affected much of the valley. Although it is possible that the onset of particular types of deposition may have extended along the valley over time, the available radiometric dates do not support this. As a result, a general sequence of floodplain and channel environment behaviour for the lower Kennet over the last 13,000 years can be reconstructed to facilitate future research in the valley, and allow comparisons with sequences identified elsewhere. Overlaps appear in the possible ages of the different stages, reflecting the imprecision of the dating - river reaction time may have been faster than the precision of a radiocarbon date. 


\subsection{Stadial braided river: HLM3- Younger Dryas Stadial (approximately 13,000-11,500 cal. BP)}

HLM3 has a cold stage palaeoenvironmental signature, with similar sedimentology to presentday rivers with nival flow regimes significantly influenced by snowmelt and high rates of sediment supply (Bryant, 1983). The duration of this phase is difficult to determine, as radiocarbon data are not sufficiently precise, though they appear to suggest much of it may date to the last few hundred years of the Younger Dryas.

\subsection{Fluvial discharge change: HLM4- End Younger Dryas/Early Holocene ( 11,500 cal. BP)}

The bounding surface identifiable at the base of much of HLM4 indicates an oscillation in fluvial behaviour at or near the glacial/interglacial transition. The limited spatial extent of HLM4 may represent focussing of the main flow of the Kennet and, by inference a reduction in peak discharges. Taken with the increased tufa content, this may indicate a relative increase in groundwater supply to the river network. The limited palaeoecological data suggest temperatures were not as low as during deposition of HLM3. The duration of this interval cannot yet be precisely determined as radiocarbon dates from HLM4 overlap with those from the top of HLM3 and from near the base of the overlying Midgham Member.

\subsection{Reduction in flow competence: MM1- early Holocene $(\sim 11,500-10,500$ cal BP)}

The basal silts indicate a major reduction in energy within the hydrological environment with sediment supply exceeding competence. The river appears to have adopted an anastomosing form, initially working its way around high points on the former braid plain. As deposition continued, many of these high points were buried and sediment was spread across the whole floodplain by repeated avulsion events (cf. Makaske, 2001).

Although subfossil assemblages appear 'stadial' in nature, this may reflect both a lag before interglacial flora could expand and also taphonomy, as much of the material in this mineral unit is likely to have come from the reworking of unconsolidated stadial deposits on the floodplain, adjacent terrace surfaces and nearby valley slopes. Radiocarbon results are from samples resting on top of the gravels or within the silts and only provide minimum ages for the beginning of MM1's deposition. Taken with dates from HLM3/4 and MM2 the duration of the MM1 phase was between $500-1000$ years in the very earliest Holocene. 
Collins et al. Kennet Floodplain

6.4 Organic deposition: MM2 - early Holocene ( 11,000-9,800 cal. BP)

A valley wide phase of low energy and low mineral inputs resulted in extensive wetlands developing. The mechanism responsible for such extensive organic deposition is unclear at present. The character of the peat indicates low energy flow, possibly being impounded in places with variations in water levels. Three main, not necessarily exclusive, hypotheses may be proposed to explain this:

a) Bioclastic dams, i.e. accumulation of large debris, such as trunks and branches, or of living vegetation, within the channel. Although accumulations of woody debris were rarely seen at Woolhampton, they were of limited extent and did not lie within distinct channel features.

b) Mesolithic fish weirs constructed across the channels. No such structure has yet been observed at any site in the Kennet. Furthermore, with the possible exception of fires, there is little direct evidence of Mesolithic activity at Woolhampton, although it is well known in the lower Kennet (e.g. Wymer, 1962; Froom, 1963; Healy et al., 1992; Barton et al., 1998).

c) Beaver dams. Where dams impound stream flow, large lakes can form rapidly within which organic debris accumulates (Worsley, 1978; Coles, 1992; Butler, 1995). Beaver (Castor fiber L.) bones have been found at other sites in the Kennet (e.g. Palmer, 1872-5), though not at Woolhampton. No feature that could be identified as a dam has yet been observed.

\subsection{Tufa river: MM3/4 ( 10,500-post 8,000 cal. BP)}

Although tufa occurs within most of the lower Kennet units, it is only an extensive component in units MM3 and MM4. The increase in tufa formation implies a significant groundwater input and, by inference enhanced infiltration and dissolution of chalk in the catchment. Initially, this tufa formed in pools on the surface of the peat, perhaps on a seasonal basis. Younger granular tufa (MM4) demonstrates a hydrological change that affected much of the valley floor. The cause of this may have been climatic, perhaps with an increase in precipitation and a slight rise in temperature. It is possible that it is also, in part, a consequence of continued tufa formation, with tufa build up constricting flow and leading to turbulence-induced precipitation.

\subsection{Mid-Holocene stability: Top of MM4}


Collins et al. Holocene Kennet

The silty bed at the top of the MM4 at Woolhampton post-dates the main phase of tufa deposition at the site. A similar reduction in tufa formation after around 3,500 cal BP is recorded across Europe (Ford and Pedley, 1996). Climate change could be involved, though, while reducing the potential for tufa formation in one area, this might produce more favourable conditions elsewhere and there is no conclusive evidence for this in Europe (Goudie et al., 1993).

The increase in non-carbonate mineral matter in the uppermost bed of MM4 may partly be a result of in situ pedogenically-related dissolution, leaving a carbonate-deficient mineral soil. The amount of non-carbonate mineral sediment present also suggests accelerated soil erosion in the catchment, perhaps due to farming. However, there is only limited palaeoecological evidence to indicate local woodland disturbance. Changes in river behaviour in the upper Kennet at this time were clearly influenced by people, where woodland clearance, beginning in the Neolithic, led to alluviation (Evans et al., 1993).

\subsection{Mid Holocene flooding: MM5}

The coarse sediment in MM5 indicates episodic high-energy flood events probably related to reduced water storage on valley slopes and terraces cleared for agriculture. Increased wetness at around 2600 BP (Van Geel et al., 1996; Mauquoy and Barber, 1999) may also have contributed to the flooding. Peat began to form in the tributary Lambourn valley at 2750-2390 BP (HAR-4241), possibly reflecting wetter conditions and local land use change (Waton, 1982).

\subsection{Alluviation: MM6 - late Holocene (post 3,000 cal. BP)}

MM6 reflects the most recent phase of deposition affecting the floodplain. The process responsible is clearly overbank flow. A number of extensive floods have affected the valley since the Roman occupation (Collins, 1994). Pope Nicholas $V$ referred to a significant flood in 1453 AD that made several roads in the area impassable (Parsons, 1930). Interestingly, this coincides with a 'wet' interval recorded elsewhere in the British Isles (e.g. Chambers et al., 1997). In recent floods, for example in 1993 and 2002, large amounts of silt, sand and gravel, often with a high tufa content, were scoured from floodplain fields as water overflowed from the Enborne near Woolhampton. Some of this material was redeposited as small deltas on the margins of the slightly lower floodplain of the 
Collins et al. Kennet Floodplain

Kennet. Overbank deposits were also seen across the floodplains of both the Kennet and Enborne. Much of this sediment has now been incorporated into the top of MM6.

In contrast, this period appears to have been marked by general stability on the floodplain In the upper Kennet valley (Evans et al., 1993), perhaps reflecting locally successful soil conservation. Continued alluviation in the lower Kennet may reflect downstream reworking of sediment already within the river system, together with continued erosion elsewhere in the catchment.

The implication of the sedimentological, biostratigraphical, archaeological, documentary and present-day process observations is that MM6 has developed at Woolhampton and elsewhere in response to episodic flooding over perhaps the last two to three thousand years.

\section{Comparison with change in northwest Europe.}

Previous considerations of the behaviour of a number of north-west European rivers (e.g. Macklin and Lewin, 1993; Vandenberghe, 1995; Gibbard and Lewin, 2002; Lewin et al., 2005) indicate that, while each river has a unique history and some differences exist across the region, some similarities are discernable. Gibbard and Lewin propose a sedimentation model of seven fluvial phases (Fphi-Fphvii) covering glacial-interglacial cycles for mid-late Pleistocene rivers in lowland Britain. This model, which draws largely upon the pre-Holocene fluvial archive, provides a useful baseline against which Holocene fluvial sequences (e.g. those identified in Fig. 1) can be compared.

\subsection{Full and Lateglacial}

The presence of thick sequences of braided river deposits in the Kennet valley, ${ }^{14} \mathrm{C}$ dated to the latter part of the Younger Dryas Stadial, appears to match an increase in dates from similar deposits elsewhere in Britain (Rose et al., 1980; Rose 1995; Lewis et al., 2001; Lewin et al., 2003) and some rivers in northwest Europe, for example the Vistula in Poland (Starkel, 2002) and Maas in Belgium and the Netherlands (Kasse et al., 1995; Tebbens et al., 1999). Not all rivers adopted a braided plan form. A meandering system appears to have been present in the Upper Rhine in Germany (Dambeck \& Thiemeyer, 2002), Dneister (Huhmann et al., 2003) and Spree in eastern Germany (Kaase et al., 2003). Some rivers, e.g. in central Germany (Hagedorn \& Rother, 1992), exhibited both braided and meandering forms. In contrast, low energy conditions appear to have prevailed in some river valleys - calcareous silts have been recorded in the Paris Basin (Antoine et 
al., 2003; Pastre et al., 2003) and Vandenberghe et al. (1984) report organic deposits in valleys from north Belgium, though this latter feature probably relects blockage of flow by aeolian deposits.

\subsection{Lateglacial-Holocene substage I ( Fph i)}

Gibbard and Lewin (2002) suggest an 'inevitable lag' of over 500 years before rivers responded to the Early Holocene climatic amelioration. The Kennet appears to have responded much more rapidly, with an initial disturbance (represented by HLM4) perhaps occurring right at the glacialinterglacial transition. This minor scour may correspond temporally with the more extensive incision experienced elsewhere. Incision has been identified in the Upper and Lower Thames (Lewis et al., 2001; Sidell et al., 2000) and in some rivers in continental Europe, for example the Dneister (Huhmann et al., 2003), the Maas (Kasse et al., 1995; Tebbens et al., 1999) and the Paris Basin (Antoine et al., 2003; Pastre et al., 2003). Following this, there was very rapid accumulation of finegrained sediment in the Kennet, with up to $2.5 \mathrm{~m}$ of silt, sand and clay being deposited in a few hundred years. While the flow at the start of this period may have exploited existing braidplain channels as reported elsewhere (e.g. Gibbard, 1985; Brown et al., 1994), it is apparent that these rapidly became infilled and flow spread across the valley floor, probably in an anastomosing form. Although temporal control is less precise, a similar event appears to have also affected the Deule in northern France (Deschodt \& Salvador, 2003) as well as rivers in southern England (Burrin \& Scaife, 1984; Scaife \& Burrin, 1992). Where sediments are preserved, most rivers elsewhere in Europe appear to have either maintained or adopted a meandering form (e.g. the Vistula - Starkel, 2002; Upper Rhine Dambeck \& Thiemeyer, 2002; southern Netherlands - Bohncke \& Vandenberghe, 1991).

\subsection{Holocene substage II ( Fph ii)}

The Kennet appears to follow the Gibbard and Lewin model, with extensive peat formation between approximately 11.2-9.8 Cal BP infilling channels and extending across the floodplain, covering all but the highest remnants of the former braidplain. No large channel has been found associated with MM2, indicating the floodplain swamp was fed by a number of smaller, possibly stable channels. Peat of a similar age is recorded elsewhere in southern England (Gibbard, 1985; Burrin \& Scaife, 1984) and from some mainland European rivers. The extent to which channel conditions were 
being affected by peat formation is unclear in most rivers, though some clearly were (e.g. in the Paris Basin - Pastre et al., 2003).

Unlike many other rivers, the Kennet then changed mode to deposit large quantities of tufa, initially in low energy pools but then within channels which migrated or avulsed across the floodplain, which was colonised by Alnus carr woodland. In the Kennet, this occurred between approximately 10.5 and 4.0 Cal BP, though the dating control is not precise. Low energy conditions have been identified in an number of river channels across the region, for example peat may have continued to form in the Selle (Antoine et al., 2003) and there was reduced flow in the southern Netherlands (Bohncke \& Vandenberghe 1991) and north Belgium (Vandenberghe et al., 1984). In the majority of rivers across northwest Europe, however, this period was characterised by meandering behaviour, for example in the Loire in south-central France (Colls et al., 2001), Teleorman in Romania (Howard et al., 2004), Vistula (Starkel, 2002) and Upper Rhine (Dambeck \& Thiemeyer, 2002), with some episodes of incision e.g. in the Dneister (Huhmann et al. 2003).

The end of this phase, as with many other rivers (Macklin, 1999), saw stability of the floodplain surface. This probably reflects low sediment supply. As discussed above, cessation of tufa formation may in part reflect a relative decline in groundwater supply due to prehistoric clearances. The fact that there was no extensive non-carbonate clastic deposition suggests that most of the runoff was accommodated within existing channels.

\subsection{Holocene substage III ( Fph iii)}

This phase, which in Gibbard and Lewin's model is marked by overbank deposits, begins in the Kennet with a major flood or series of floods, during which earlier deposits were eroded and redeposited (MM5). Evidence for higher energy fluvial behaviour has been reported at mid-Holocene sites in the Thames (Needham, 1992) and elsewhere in the British Isles (e.g. Macklin et al., 1992; Howard et al., 1999). Across Europe, between 6.0-3.0 Cal BP, many rivers change behaviour. Where there had been a prolonged period of low energy conditions, erosion was common, for example in the southern Netherlands after 5.0 Cal BP (Bohncke \& Vandenberghe, 1991), and in the Mark Valley, Belgium, between approximately 4.0-3.0 Cal BP (Vandenberghe et al., 1984). The Dneister experienced an increased sediment load after approximately 6.0 Cal BP (Huhmann et al., 
2003), while the Upper Rhine (Dambeck and Thiemeyer, 2002) experienced an episode of incision at about 5.0 Cal BP, followed by a shift to a larger amplitude meandering planform. In the Loire (Colls et al., 2001) and Teleorman (Howard et al., 2004), the rivers appear to have shifted from generally stable meandering forms to ones which saw alternations between incision and aggradation. This distinctive sedimentary feature appears absent from deposits relating to pre-Holocene interglacials.

On their own, the series of climatic shifts since at least 5,500 cal BP (McDermott et al., 1999) may not have been sufficient to trigger such events. In most cases, however, these changes coincided with significant change in catchment conditions resulting from the expansion of agriculture. As a result, groundwater levels may have been higher, interception lower and surface runoff greater (cf. Robinson and Lambrick, 1984; Favis-Mortlock et al., 1997), producing flow regimes unlike any other experienced since the Lateglacial.

The final episode of inorganic deposition identified in the lower Kennet (MM6) correlates with a regional change in fluvial regime beginning in the Iron Age (e.g. Robinson and Lambrick, 1984; Vandenberghe et al., 1984; Robinson, 1992; Sidell et al., 2000; Howard et al., 2004). In some areas, such as the lower Kennet valley, there is a clear link with the expansion of pastoral and arable agriculture (e.g. the Severn - Brown and Barber, 1985), which increased the potential sensitivity of the catchment systems to climate change (Macklin and Lewin, 1993). There is considerable variability, however, reflecting differences in catchment conditions and probably also direct intervention with the river channel, for example weirs, straightening, dredging and water extraction.

In the upper Kennet, this period appears to have been marked by general floodplain stability (Evans et al., 1993), perhaps reflecting locally successful soil conservation. Continued alluviation in the lower Kennet may reflect downstream reworking of sediment already within the river system, together with continued erosion elsewhere in the catchment.

\section{Fluvial sensitivity to change}

The pattern of phases of instability and stability over time recorded in Lateglacial and Holocene fluvial landforms and sediments across northwest Europe is similar to the climatic forcing model of Vandenberghe (1995), based upon glacial-interglacial adjustments. In this theoretical model, fluvial response occurs immediately after a climatic shift with a phase of erosion followed by deposition. In the lower Kennet valley and elsewhere, changes in state occurred as pulses. These 
Collins et al. Kennet Floodplain

pulses correlate closely with periods of significant environmental change in the catchment. Age control is not sufficient to determine the rate of change during the Middle to Late Holocene but, at the Lateglacial-Holocene transition, the rate of response is rapid and perhaps much more abrupt than in some other river systems.

A partial explanation for the difference between the Kennet and some other rivers is catchment size - the Kennet is a medium-size river and may be inherently more sensitive to external forcing than larger river systems.

A further difference is in Quaternary history. As noted previously, with the exception of a very few clasts of non-local origin and some aeolian material, there is no evidence for significant extracatchment supply of unconsolidated sediment. Many other rivers across northwest Europe have been directly influenced by glacial incursion, loess and coversand deposition or, in the case of some rivers, eruption-derived materials such as the Laacher See Tephra (Litt et al., 2003).

A third, and arguably equally important cause of this rate of response may be in the pronounced difference in the balance between surface runoff and groundwater supply to the river. This would have varied between cold and warm climates, most likely through the nature and timing of precipitation and infiltration. As noted above, there is no conclusive evidence that permafrost was present in the catchment. As a result, ground drainage during cold stage summer months may not have been that different from present as temperatures were still well above freezing (Coope and Lemdahl, 1995). In contrast, low winter temperatures (Witte et al., 1998) are likely to have led to seasonally frozen ground and the accumulation of snow, resulting in limited winter infiltration and thaw-induced runoff. Once an interglacial climate was established, and with no likelihood of residual permafrost, an infiltration-groundwater hydrological system would quickly have become established. A partial reversal of this occurred following extensive prehistoric forest clearance, perhaps with a similar rapid response.

\section{Conclusion}

In general, and like many northwest European rivers, the Kennet follows the Gibbard and Lewin (2002) model of sedimentation phases, with two significant differences that demonstrate the 
Collins et al. Holocene Kennet

importance of understanding local catchment conditions and careful use of geochronology when interpreting fluvial sequences:

- The rate of response to major environmental change (at least during the Lateglacial-Holocene transition) appears faster than in some other river systems, perhaps because of the sensitivity of the balance between groundwater and runoff supply.

- The abundance of easily dissolved chalk in the catchment means that, when flow sustenance is dominated by groundwater supply with a high solute load, extensive tufa deposition leads to a modified flow regime.

Despite these important differences associated with a soft limestone catchment, the results from the Kennet are broadly in agreement with the patterns found elsewhere, especially for the period before significant human impacts. This demonstrates a regional response to climatic controls. The local differences highlight the potential sensitivity of fluvial systems to environmental change.

\section{Acknowledgements}

Successive quarry owners - Steetley Quarry Products, Redlands, and now Lafarge Redlands Aggregates - have kindly facilitated access to the Woolhampton site. Drs D. Case, P. Gibbard, S. Marriott, A. Veldkamp, R. Tipping and W. Woodland and two anonymous reviewers are thanked for valued comments on earlier versions of this paper. 
Collins et al. Kennet Floodplain. Captions.

Figures:

1. Northwest Europe, showing the locations of the Kennet and other rivers and areas mentioned in the text: a) Thames; b) southern England; c) Severn; d) Gipping; e) Tyne; f) Paris Basin; g) Deule; h) Selle; i) Loire;

j) Mark; k) southern Netherlands; I) Maas/Meuse; m) Lower Saxony; n) Ohm \& Wetter; o) Upper Rhine; p) Spree; q) Vistula; r) Dneister; s) Teleorman.

2. DEM of the lower Kennet valley, viewed from the south, showing the location of sites: 1) Woolhampton; 2) Thatcham; 3) Theale; 4) Burghfield Mill; 5) Halfway; 6) Avington; 7) Wawcott; 8) Avenell's Cottages; 9) Greenham Dairy Farm; 10) Sulhampstead; 11) Aldermaston; 12) Snelsmore Bog.

3. a) Geomorphology of the valley floor near Woolhampton, based on field survey, showing the locations of sections MM\#A and MM\#B. Reconstructed courses for the Kennet during deposition of HLM4 and MM5 are shown. b) Cross-section showing the relationship between MM5 and the rest of the Midgham Member, resting upon the Heales Lock Member. Drawn from a series of photographs taken in February 1991: position shown as line between $X^{1}$ and $X^{2}$ in Fig $2 a$.

4. a) North-south cross section of the lower Kennet valley at Woolhampton, showing major morphostratigraphic features and sediment unit ages (modified from Worsley \& Collins 1995). b) 
Schematic west-east cross section of the internal structure of the Midgham and Heales Lock Members at Woolhampton showing the main stratigraphic subunits. Compiled from quarry exposures examined between 1990-2000 and borehole data.

5. Pollen percentage diagram of MM\#A, showing relationships of assemblages to stratigraphic units. All frequencies are expressed as percentages of Total Land Pollen (TLP).

6. Pollen percentage diagram of MM\#B. Note the change of scale for the microscopic charcoal fragment frequency, which is expressed as a percentage of TLP.

7. Comparison of Holocene deposits from sites in the lower Kennet.

8. Probability plots for radiocarbon dates from fluvial sedimentary contexts in the lower Kennet valley, calculated using OxCal v3.9 (Bronk Ramsey, 2003), showing the age ranges for the different Lateglacial and early Holocene units (black boxes indicate most likely ages, based upon two standard deviation ranges and sample characteristics.

\section{Supplementary tables:}

1. Radiocarbon dates from the lower Kennet valley, showing sample characteristics, associated palaeoenvironments and calibrated ages. Calibrated dates have been determined at two standard deviation ranges using OxCal 3.9 (Bronk Romsey 2003).

2. Pollen percentage data from samples from Unit HLM4. Samples coded C1-7 are from a channel feature, samples T1-2 are from a tufa bed. 
3. Mollusca retrieved from monolith sample MM\#A at Woolhampton. 


\section{References}

Andrenn T., Björkn J., Johnsenn S. 1999. Correlation of Swedish glacial varves with the Greenland (GRIP) oxygen isotope record. Journal of Quaternary Science 14, 361-371.

Antoine, P., Munaut A.-V., Limondin-Lozouet, N., Ponel P., Dupéron J., Dupéron M. 2003. Response of the Selle River to climatic modifications during the Lateglacial and early Holocene (Somme Basin-North France). Quaternary Science Reviews 22, 2061-2076.

Barber, K.E., Maddy, D., Rose, N., Stevenson, A.C., Stoneman, R., Thompson, R. 2000.Replicated proxy-climate signals over the last $2000 \mathrm{yr}$ from two distant UK peat bogs: new evidence for regional palaeoclimate teleconnections. Quaternary Science Reviews 19, 481-487.

Barton, R.N.E., Antoine, P., Dumont, S., Hall, S., Munaut A.V. 1998. New optically stimulated luminescence (OSL) dates from a Late-glacial site in the Kennet Valley at Avington VI, Berkshire, UK. Quaternary Newsletter 85, 21-31.

Baumgart-Kotarba, M. 1989. Mechanism of braided alluvial plain formation - coarse gravel sedimentary environment as example. Quaestiones Geographicae Special Issue 2, 5-16.

Bennett, K.D., Preece R.C. 1998. Palaeobotany. In: Preece, R.C., Bridgland, D.R. (Eds.) Late Quaternary Environmental Change in North-west Europe - Excavations at Holywell Coombe, South-east England. Chapman \& Hall, London, pp. 123-148.

Bennett, K.D., Whittington, G., Edwards ,K.J. 1994. Recent plant nomenclatural changes and pollen morphology in the British Isles. Quaternary Newsletter 73, 1-6.

Björk, S. Walker, M.J.C., Cwynar, L., Johnsen, S.J., Knudsen, K.L., Lowe, J.J., Wohlfarth, B. \& INTIMATE Members 1998. An event stratigraphy for the Last Termination in the North Atlantic based upon the Greenland Ice Core record: a proposal by the INTIMATE group. Journal of Quaternary Science 13, 283-292.

Bohncke, S., Vandenbeghe, J.1991. Palaeohydrological development in the southern Netherlands during the last 15,000 years. In: Starkel, L., Gregory, K.J., Thornes, J.B. (Eds.) Temperate Palaeohydrology. Wiley, Chichester, pp. 253-281.

Bradford, R.B. 2002. Controls on the discharge of Chalk streams of the Berkshire Downs, UK. The Science of the Total Environment 282-283, 65-80. 
Bradley, R., Lobb, S.J., Richards, J., Robinson, M. 1980. Two late Bronze Age settlements on the Kennet Gravels: excavations at Aldermaston Wharf and Knights Farm, Burghfield, Berkshire. Proceedings of the Prehistoric Society 46, 217-295.

Brauer, A., Endres, C., Negendank J.F.W. 1999. Lateglacial calendar year chronology based on annually laminated sediments from Lake Meerfelder Maar, Germany. Quaternary International $61,17-25$

Bridgland, D.R. 2000. River terrace systems in north-west Europe: an archive of environmental change, uplift and early human occupation. Quaternary Science Reviews 19, 1293-1303.

Bridgland, D.R., Allen P. 1996. A revised model for terrace formation and its significance for the lower Middle Pleistocene Thames terrace aggradations of south-east Essex. In: Turner, C. (Ed.) The Early Middle Pleistocene in Europe. Balkema, Rotterdam, pp. 123-134.

Bronk Ramsey, C. 2003. OxCal 3.9 radiocarbon calibration program. Oxford University Radiocarbon Accelerator Unit.

Brown, A.G., Barber K.E 1985. Late Holocene paleoecology and sedimentary history of a small lowland catchment in central England. Quaternary Research 24, 87-102.

Brown, A.G., Keough, M.K., Rice R.J. 1994. Floodplain evolution in the East Midlands, United Kingdom - the Late-glacial and Flandrian alluvial record from the Soar and Nene valleys. Philosophical Transactions of the Royal Society of London, Series A 348, 261-293.

Bryant, I.D. 1983. Facies sequences associated with some braided river deposits of late Pleistocene age from Southern Britain. In: Collinson J.D., Lewin J. (Eds.) Modern and Ancient Fluvial Systems. Blackwell Scientific, Oxford, pp. 267-275.

Buckland, W. 1825. Extract from "On the formation of the Valley of Kingsclere and other valleys by the elevation of the strata that enclose them, and on the evidences of the original continuities of the Basins of London and Hampshire" reprinted in Transactions of the Newbury District Field Club 2, 138-141.

Burrin, P.J., Scaife, R.G. 1984. Aspects of Holocene valley sedimentation and floodplain development in southern England. Proceedings of the Geologists' Association 95, 81-96.

Butler, D.R. 1995. Zoogeomorphology: Animals as Geomorphic Agents. Cambridge University Press, Cambridge. 
Collins et al. Kennet Floodplain

Butterworth, C.A., Lobb S.J. 1992. Excavations in the Burghfield area, Berkshire - Developments in the Bronze Age and Saxon Landscapes. Wessex Archaeology Report No. 1, Wessex Archaeology, Salisbury.

Chambers, F.M., Barber, K.E., Maddy, D., Brew J. 1997. A 5500-year proxy-climate and vegetation record from blanket mire at Talla Moss, Borders, Scotland. The Holocene 7, 391-399.

Champness, C. 1999. Early Holocene environmental change and human activity in the Kennet valley, Berkshire. Unpublished MSc thesis, University of Reading.

Chartres, C.J. 1975. Soil Development on the Terraces of the River Kennet. Unpublished PhD Thesis, University of Reading.

Chartres, C.J. 1980. A Quaternary soil sequence in the Kennet valley, central southern England. Geoderma 23, 126-146.

Chartres, C.J. 1981. The mineralogy of Quaternary deposits in the Kennet Valley, Berkshire. Proceedings Geologists' Association 92, 93-103.

Cheetham, G.H. 1975. Late Quaternary Palaeohydrology, with reference to the Kennet Valley. Unpublished PhD thesis, University of Reading.

Cheetham, G.H. 1980. Late Quaternary palaeohydrology: the Kennet Valley case-study. In: Jones, D.K.C. (Ed.) The Shaping of Southern England. Institute of British Geographers Special Publication 11, pp 203-223.

Churchill, D.M. 1962. The stratigraphy of Mesolithic sites III and V at Thatcham, Berkshire, England. Proceedings of the Prehistorical Society 28, 361-370.

Coles B. 1992. Further thoughts on the impact of beaver in temperate landscapes. In Needham S. \& Macklin M.G. (editors) Alluvial Archaeology in Britain. Oxbow Monograph 27, pp. 93-99.

Collins, P.E.F. 1994. Floodplain Environmental Change since the Last Glacial Maximum in the Lower Kennet Valley, South-central England. Unpublished Ph.D. thesis, University of Reading.

Collins, P.E.F. 1999. Kennet and Pang vallies. In: Bowen, D.Q. (Ed.) A Revised Correlation of Quaternary Deposits in the British Isles. Geological Society Special Report No. 23, pp. 51-53.

Collins, P.E.F., Fenwick, I.M., Keith-Lucas, D.M., Worsley, P. 1996. Late Devensian river and floodplain dynamics in northwest Europe, with particular reference to a site at Woolhampton, Berkshire, England. Journal of Quaternary Science 11, 357-375. 
Colls, A.E., Stokes, S., Blum, M.D., Straffin, E. 2001. Age limits on the Late Quaternary evolution of the upper Loire River. Quaternary Science Reviews 20, 743-750.

Coope, G.R., Lemdahl, G. 1995. Regional differences in the Lateglacial climate of northern Europe based on coleopteran analysis. Journal of Quaternary Science 10, 391-395.

Dambeck, R., Thiemeyer, H. 2002. Fluvial history of the northern Upper Rhine River (southwestern Germany) during the Lateglacial and Holocene times. Quaternary International 93-4, 53-63.

Day, S.P., 1991. Post-glacial vegetational history of the Oxford region. New Phytologist 119, 445-470.

Deschodt, L., Salvador, P.G. 2003. Contribution to our knowledge of the palaeoenvironment of the Deule River valley (Nord, France): a stratigraphical approach. Revue du Nord 85, 23-33.

Ellis, A.E. 1978. British Freshwater Bivalve Mollusca. Synopses of the British Fauna No. 11. Academic Press, London.

Evans, J.G., Limbrey, S., Máté, I., Mount R. 1993. An environmental history of the upper Kennet valley, Wiltshire, for the last 10,000 years. Proceedings of the Prehistoric Society 59, 139-195.

Favis-Mortlock, D.T., Boardman, J., Bell, M. 1997. Monitoring long-term anthropogenic erosion of a loess cover: South Downs UK. The Holocene 7, 79-89

Ford, T.D., Pedley, H.M. 1996. A review of tufa and travertine deposits of the world. Earth-Science Reviews 41, 117-175.

Froom, F.R. 1963. The Mesolithic around Hungerford - part III - excavations at Wawcott IV. Transactions of the Newbury District Field Club 11, 74-87.

Gibbard, P.L. 1985. Pleistocene history of the Middle Thames Valley. Cambridge University Press, Cambridge.

Gibbard P.L. 1999. Middle Thames and the Vale of St. Albans. In Bowen D.Q. (Ed.) A Revised Correlation of Quaternary Deposits in the British Isles. Geological Society Special Report No. 23, pp. $48-50$.

Gibbard, P.L., Lewin, J. 2002. Climate and related controls on interglacial fluvial sedimentation in lowland Britain. Sedimentary Geology 151, 187-210.

Goudie, A.S., Viles H.A., Pentecost, A. 1993. The late-Holocene tufa decline in Europe. The Holocene 3, 181-186.

Hagedorn, J., Rother, N. 1992. Holocene floodplain evolution of small rivers in the uplands of Lower Saxony, Germany. Geomorphology 4, 423-432. 
Hayward, M., 1985. Soil development in Flandrian floodplains: River Severn case-study. In: Boardman, J. (Ed.) Soils and Quaternary Landscape Evolution. John Wiley \& Sons, Chichester, pp. 281-299.

Healy, F., Heaton, M., Lobb, S.J. 1992. Excavations of a Mesolithic site at Thatcham, Berkshire. Proceedings of the Prehistoric Society 58, 41-76.

Holyoak, D.T. 1980. Late Pleistocene Sediments and Biostratigraphy of the Kennet Valley, England. Unpublished PhD thesis, University of Reading.

Holyoak, D.T. 1983. The colonisation of Berkshire, England, by land and fresh-water Mollusca since the Late Devensian. Journal of Biogeography 10, 483-496.

Howard, A.J., Smith, D.N., Garton, D., Hillam, J., Pearce, M. 1999. Middle to Late Holocene Environments in the Middle to Lower Trent Valley. In: Brown, A.G., Quine, T. (Eds.) Fluvial Processes \& Environmental Change. Wiley, Chichester, pp. 165-78.

Howard, A.J., Macklin, M.G., Bailey, D.W., Mills, S., Andreescu, R. 2004. Late-glacial and Holocene river development in the Teleorman Valley on the southern Romanian Plain. Journal of Quaternary Science 19, 271-280.

Huhmann, M., Kremenetski, K.V., Hiller, A., Brückner, H. 2003. Late Quaternary landscape evolution of the upper Dneister valley, western Ukraine. Palaeogeography, Palaeoclimatology, Palaeoecology 209, 51-71.

Jacobi, R.M. 1987. Misanthropic miscellany: musings on British Early Flandrian archaeology and other flights of fancy. In: Rowley-Conway, P, Zvelebil, M., Blankholm, H.P. (Eds.) Mesolithic North-west Europe: Recent Trends. Department of Archaeology, University of Sheffield, pp. 163168.

Kaase, C., Vandenberghe, J., Bohncke, S. J. P. 1995. Climatic change and fluvial dynamics of the Maas during the late Weichselian and early Holocene. Palaeoclimate Research 14, 123-150.

Kaase, C., Vandenberghe, J., Van Huissteden, J., Bohncke, S. J. P., Bos, J. A. A. 2003. Sensitivity of Weichselian fluvial systems to climate change (Nochten mine, eastern Germany). Quaternary Science Reviews 22, 2141-2156

Kerney, M.P., Cameron R.A.D. 1979. A Field Guide to the Land Snails of Britain and North-west Europe. Collins, London. 
Lehman, S.J., Keigwin, L.D. 1992. Sudden changes in North Atlantic circulation during the last deglaciation. Nature 356, 757-762.

Lewin, J., Macklin, M.G., Johnstone, E. 2005. Interpreting alluvial archives: sedimentological factors in the British Holocene fluvial record. Quaternary Science Reviews 24, 1873-1889.

Lewis, S.G., Maddy, D., Scaife, R.G. 2001. The fluvial system response to abrupt climate change during the last cold stage: The Upper Pleistocene River Thames fluvial succession and Ashton Keynes, UK. Global and Planetary Change 28, 341-359.

Limbrick, K.J., Whitehead, P.G., Butterfield, D., Reynard, N. 2000. Assessing the potential impacts of various climate change scenarios on the hydrological regime of the River Kennet at Theale, Berkshire, south-central England, UK: an application and evaluation of the new semi-distributed model, INCA. Science of the Total Environment 251/252, 539-555.

Litt, T., Schmincke, H-U., Kromer, B. 2003. Environmental response to climatic and volcanic events in central Europe during the Weichselian Lateglacial. Quaternary Science Reviews 22, 7-32.

Macklin, M., Lewin, J. 1993. Holocene river alluviation in Britain. Zeitschrift für Geomorphology Supplement 85, 109-122.

Macklin, M.G., Passmore, D.G., Rumsby, B.T. 1992. Climatic and cultural signals in Holocene alluvial sequences: the Tyne basin, northern England. In: Needham, S., Macklin, M.G. (Eds). Alluvial Archaeology in Britain. Oxbow Monographs 27, Oxford, pp. 123-139.

Makaske, B. 2001. Anastomosing rivers: a review of their classification, origin and sedimentary products. Earth Science Reviews 53, 149-196.

Mathers, S.J., Smith, N.J.P. 2000. Geology of the Reading district, a brief description of the geological map - Sheet 268. British Geological Survey, Keyworth.

Mauquoy, D., Barber, K. 1999. A replicated 3000 yr proxy-climate record from Coom Rigg Moss and Felecia Moss, the Border Mires, northern England. Journal of Quaternary Science 14, 263-275.

Mayle, F.E., Cwynar L.C. 1995. Impact of the Younger Dryas cooling event upon lowland vegetation of Maritime Canada. Ecological Monographs 65, 129-154.

McDermott, F., Frisia, S., Huang, Y, Longinelli, A., Spiro, B., Heaton, T.H.H., Hawkesworth, C.J., Borsato, A., Keppens, E., Fairchild, I.J., van der Borg, K., Verheyden, S., Selmo, E. 1999. Holocene climate variability in Europe: evidence from $\delta^{18} \mathrm{O}$, textural and extension-rate variations in three speleothems. Quaternary Science Reviews 18, 1021-1038. 
Miall, A.D. 1977. A review of the braided-river depositional environment. Earth Science Reviews 13, $1-62$.

Miall, A.D. 1990. Principles of Sedimentary Basin Analysis. 2nd Edition. Springer-Verlag, New York. Moore, P.D., Webb, J.A., Collinson, M.E. 1991. Pollen Analysis. $2^{\text {nd }}$ edition. Blackwell, Oxford.

Needham, S. 1992. Holocene alluviation and interstratified settlement evidence in the Thames valley at Runnymede Bridge. In: Needham, S., Macklin, M.G. (Eds). Alluvial Archaeology in Britain. Oxbow Monographs 27, Oxford, pp. 249-260.

Ordóñez, S., García del Cura, M.A. 1983. Recent and Tertiary fluvial carbonates in Central Spain. In: Collinson, J.D., Lewin, J. (Eds.). Modern and Ancient Fluvial Systems. Blackwell Scientific, Oxford, pp. 484-497.

Palmer, S. 1872-5. On the antiquities found in the peat of Newbury. Transactions of the Newbury District Field Club 2, 123-134.

Parsons, F.G. 1930. Archaeological notes: Speenhamland skeleton. Transactions of the Newbury District Field Club 6, 33-34.

Pastre, J-F., Limondin-Lozouet, N., Leroyer, C., Ponel, P., Fontugne, M. 2003. River system evolution and environmental changes during the Lateglacial in the Paris Basin (France). Quaternary Science Reviews 22, 2177-2188.

Peake, H. 1922. Archaeological finds in the Kennet gravels near Newbury. Antiquaries Journal 2, 125130.

Peake, H.J.E. 1934. Mesolithic implements at Newbury. Transactions of the Newbury District Field Club 7, 50-51

Pedley, M., Martín, J.A.G., Ordóñez, S., del Cura M.A.G 2003. Sedimentology of Quaternary perched springline and paludal tufas: criteria for recognition, with examples from Guadalajara Province, Spain. Sedimentology 50, 23-44.

Pennington, W. 1977. The Late Devensian flora and vegetation of Britain. Philosophical Transactions of the Royal Society of London Series B 280, 247-271.

Preece, R.C. 1998a. Mollusca. In: Preece, R.C., Bridgland, D.R. (Eds.) Late Quaternary Environmental Change in North-west Europe - Excavations at Holywell Coombe, South-east England. Chapman and Hall, London, pp. 158-212. 
Preece, R.C. 1998b. Synthesis. In: Preece, R.C., Bridgland, D.R. (Eds.) Late Quaternary Environmental Change in North-west Europe - Excavations at Holywell Coombe, South-east England. Chapman and Hall, London, pp. 359-382.

Robinson, M. 1992. Environment, archaeology and alluvium on the river gravels of the South Midlands. in Needham S. \& Macklin M.G. (editors) Alluvial Archaeology in Britain. Oxbow Monograph 27, Oxford, pp. 197-208.

Robinson, M., Lambrick, G.H. 1984. Holocene alluviation and hydrology in the Upper Thames basin. Nature 308, 809-814.

Rose, J. 1995. Lateglacial and early Holocene river activity in lowland Britain. Palaeoclimate Research 14, 51-74.

Rose, J., Turner, C., Coope, G.R., Bryan, M.D.1980. Channel changes in a lowland river catchment over the last 13,000 years. In: Cullingford, R.A., Davison, D.A., Lewin, J. (Eds.) Timescales in Geomorphology. Wiley, Chichester, pp. 159-175.

Seddon, M.B., Holyoak, D.T. 1985. Evidence of sustained regional permafrost during deposition of the fossiliferous Late Pleistocene river sediments at Stanton Harcourt (Oxfordshire, England). Proceedings of the Geologists' Association 96, 53-71.

Sheridan, R., Sheridan, D., Hassell, P. 1967. Rescue excavation of a Mesolithic site at Greenham Dairy Farm, Newbury, 1963. Transactions of the Newbury District Field Club 11, 66-73.

Sidell, J., Wilkinson, K., Scaife, R., Cameron, N. 2000. The Holocene Evolution of the London Thames. MoLAS Monograph 5. Museum of London Archaeology Service.

Smith, N.D. 1974. Sedimentology and bar formation in the upper Kicking Horse River, a braided outwash stream. Journal of Geology 82, 205-223.

Stace, C. 1997. New Flora of the British Isles. Second Edition. Cambridge University Press, Cambridge.

Starkel, L. 2002. Change in the frequency of extreme events as the indicator of climatic change in the Holocene (in fluvial systems). Quaternary International 91, 25-32.

Taylor, K.C., Lamorey, G.W., Doyle, G.A., Alley, R.B., Grootes, P.M., Mayewski, P.A., White, J.W.C., Barlow L.K. 1993. The 'flickering switch' of late Pleistocene climate change. Nature 361, 432436 
Tebbens, L.A., Veldkamp, A., Westerhoff, W., Kroonenberg, S.B. 1999. Fluvial incision and channel downcutting as a response to Late-glacial and Early Holocene climate change: the lower reach of the River Meuse (Maas), The Netherlands. Journal of Quaternary Science 14, 59-75.

Thomas, M.F. 1961. River terraces and drainage development in the Reading area. Proceedings of the Geologists' Association 72, 415-426.

Vandenberghe, J. 1995. Timescales, climate and river development. Quaternary Science Reviews $14,631-638$.

Vandenberghe, J., Paris P., Kasse, C., Gouman, M., Beyens, L. 1984. Paleomorphological and botanical evolution of small lowland valleys - a case study of the Mark valley in northern Belgium. Catena 11, 229-238.

Van Geel, B., Buurman, J. \& Waterbolk, H.T. 1996. Archaeological and palaeoecological indications of an abrupt climate change in The Netherlands, and evidence for climatological teleconnections around 2650 BP. Journal of Quaternary Science 11, 451-460.

Waller, M.P. 1993. Flandrian vegetation history of south-eastern England. Pollen data from Pannel Bridge, East Sussex. New Phytologist 124, 345-369.

Waton, P.V. 1982. Man's impact on the chalklands: some new pollen evidence. In: Bell, M. and Limbrey, S. (Eds) Archaeological Aspects of Woodland Ecology. BAR International Series 146, 75-91.

Witte, H.J.L., Coope, G.R., Lemdahl, G., Lowe J.J. 1998. Regression coefficients of thermal gradients in northwestern Europe during the last glacial-Holocene transition using beetle MCR data. Journal of Quaternary Science 13, 435-445.

Wilkinson, L. 1985. A Palaeo-ecological Study of the Theale Area near Reading. Unpublished B.Sc. dissertation, Department of Botany, University of Reading.

Worsley, P. 1978. On the ecology of the beaver and some speculative applications. Quaternary Newsletter 25, 3-4.

Worsley, P., Collins P.E.F. 1995. The geomorphological context of the Brimpton Late Pleistocene succession (south central England). Proceedings of the Geologists' Association 106, 39-45.

Wymer, J. 1962. Excavations at the Maglemosian sites at Thatcham, Berkshire, England. Proceedings of the Prehistorical Society 28, 329-361. 


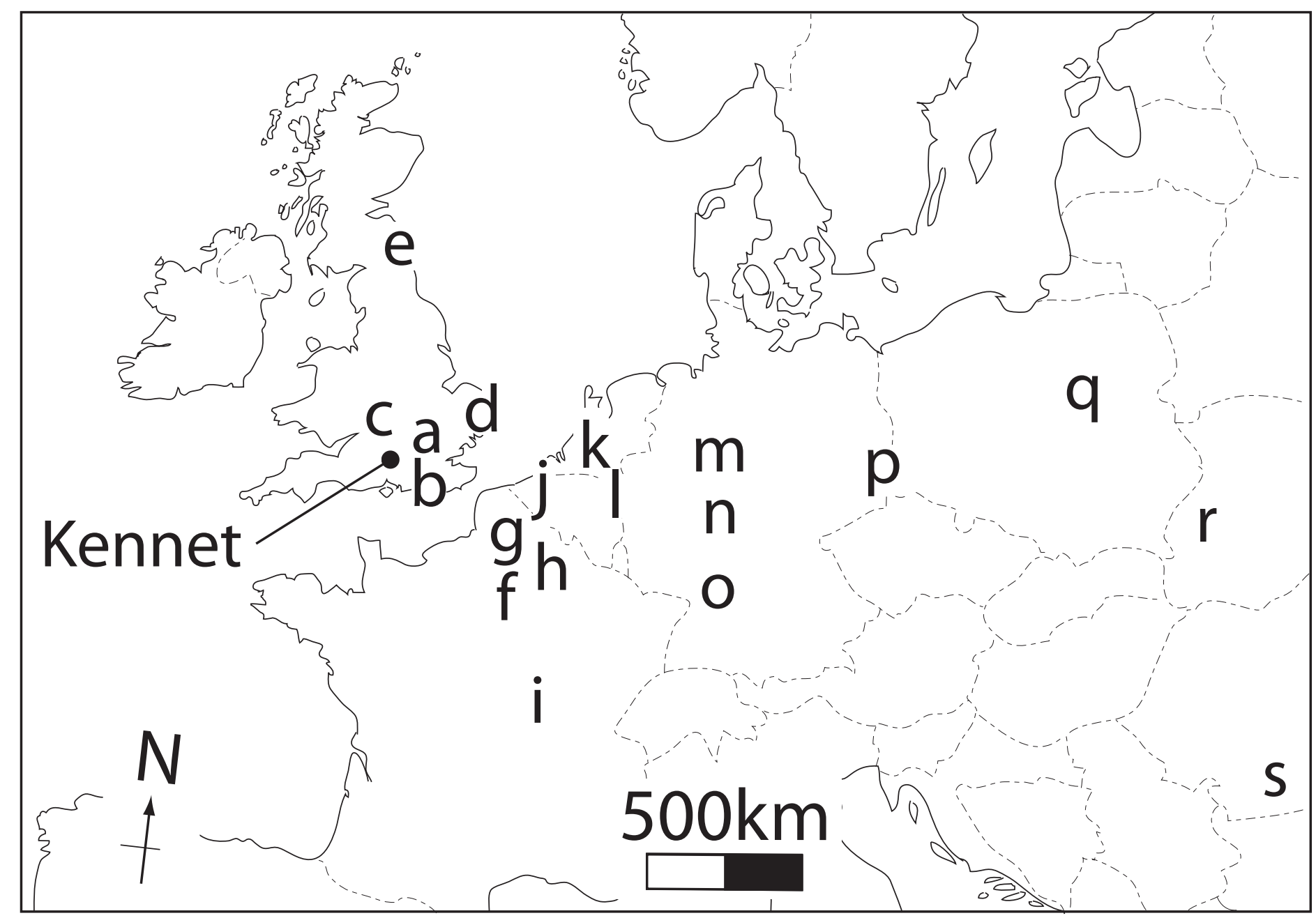




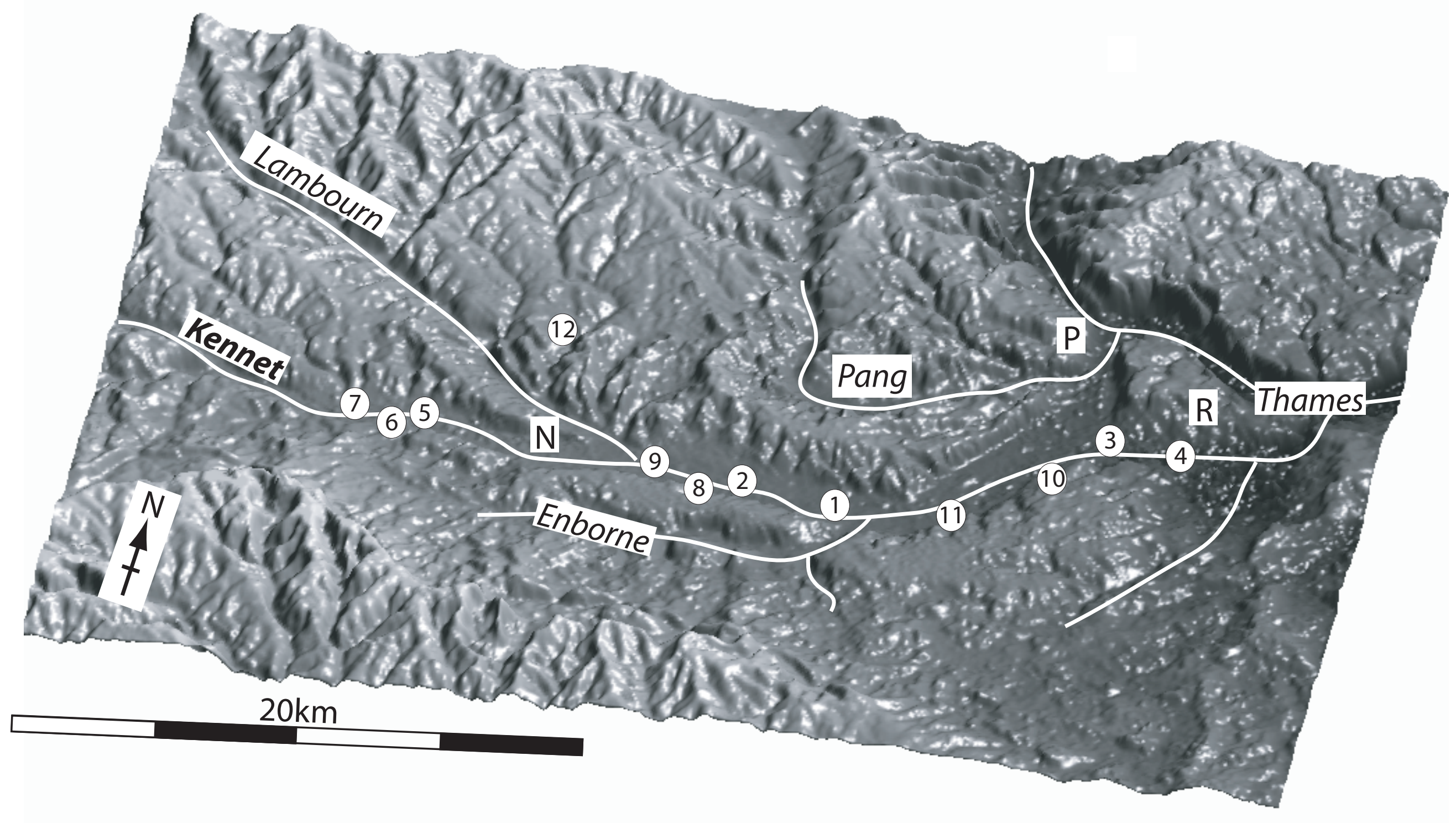




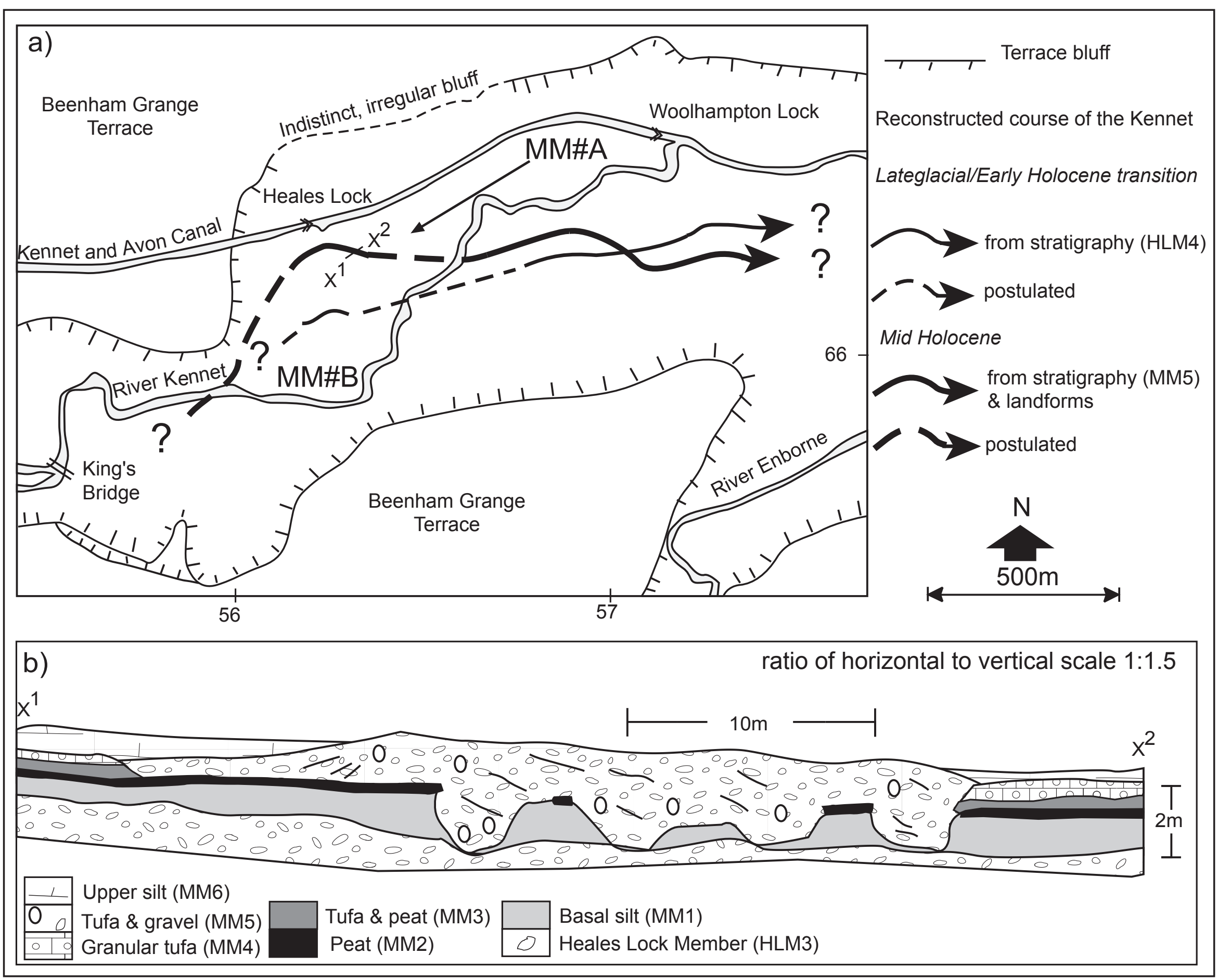


a)

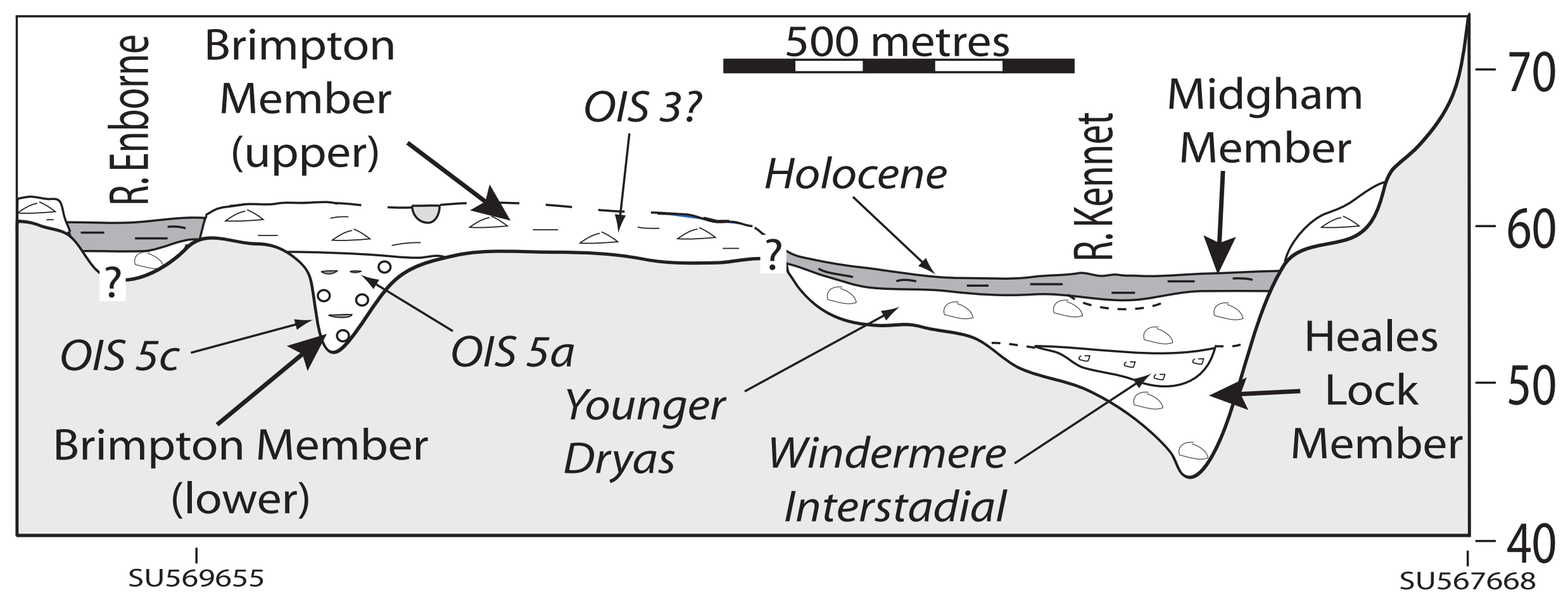

b)

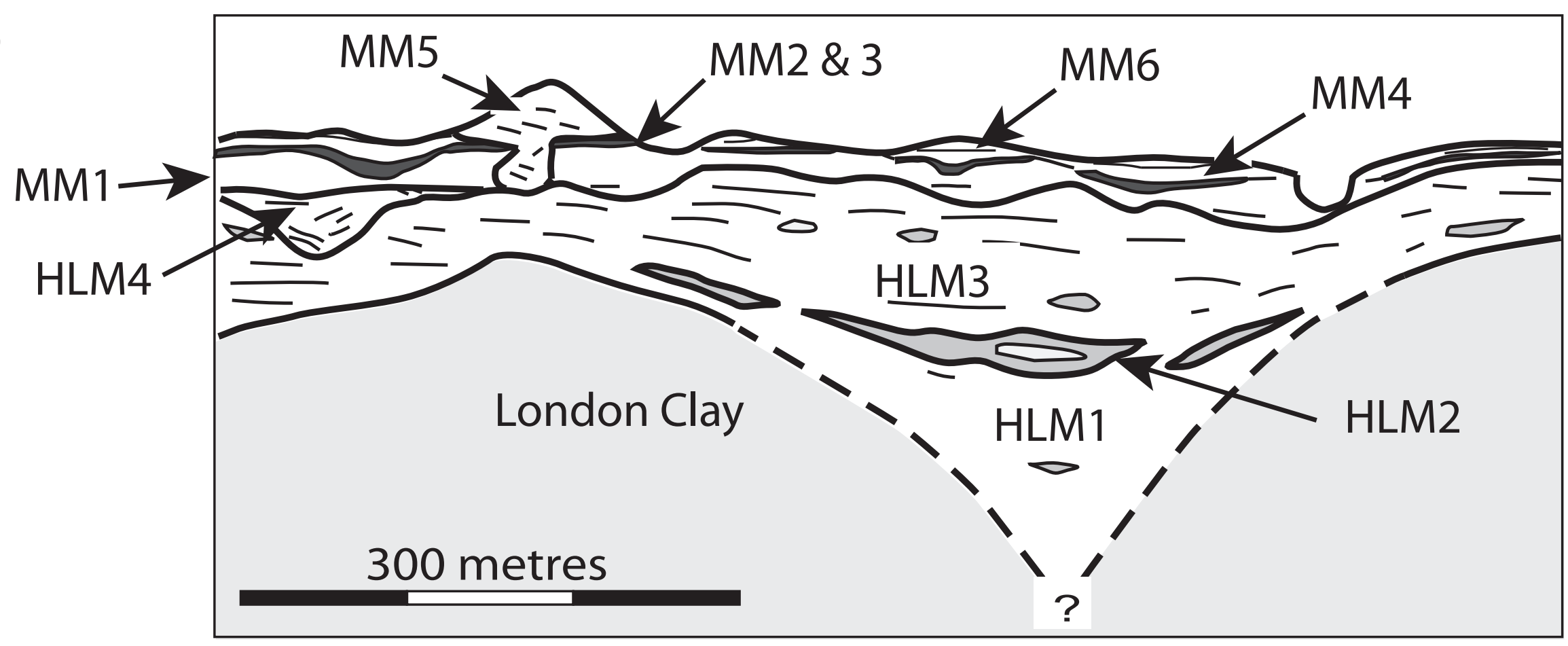



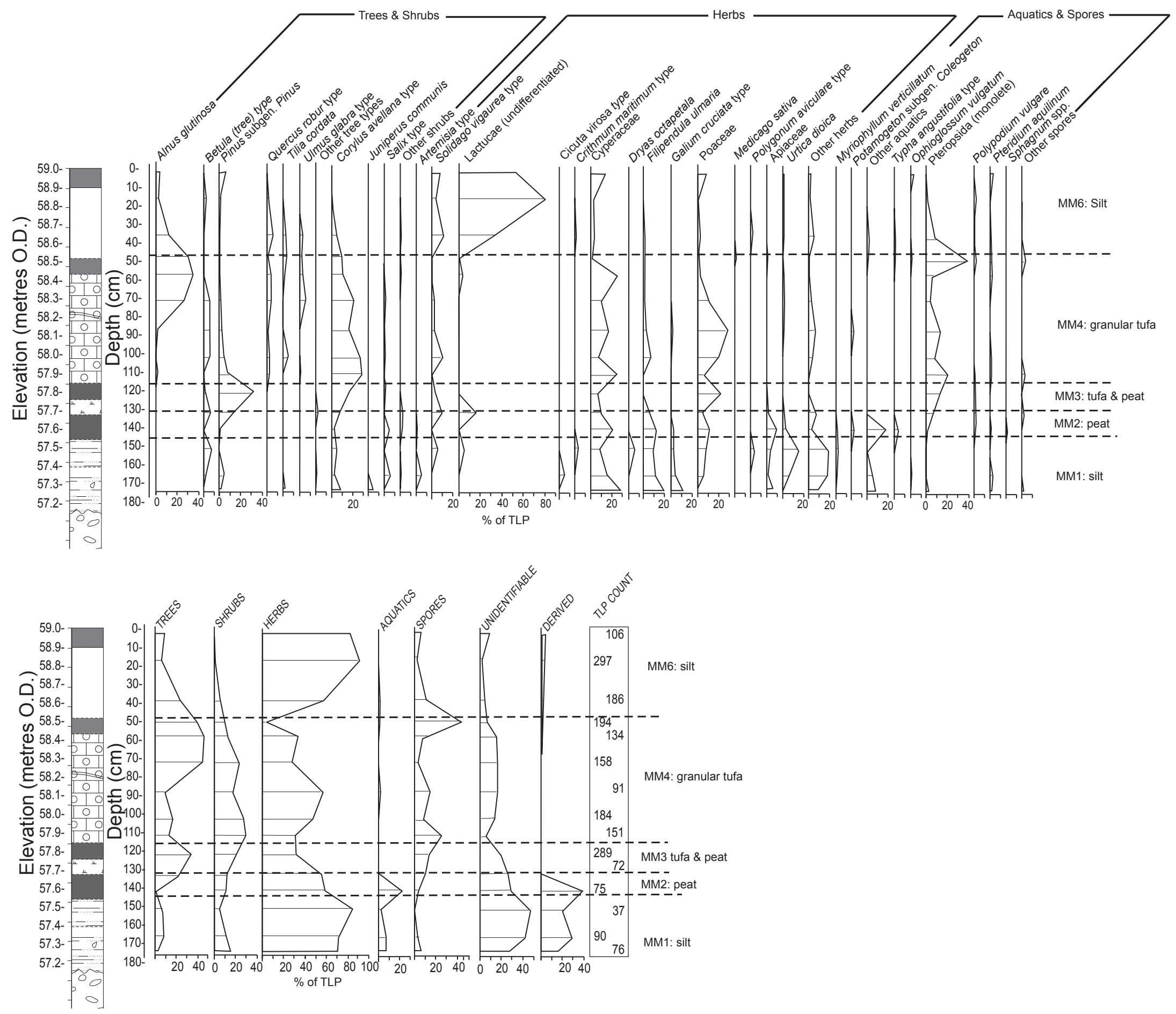


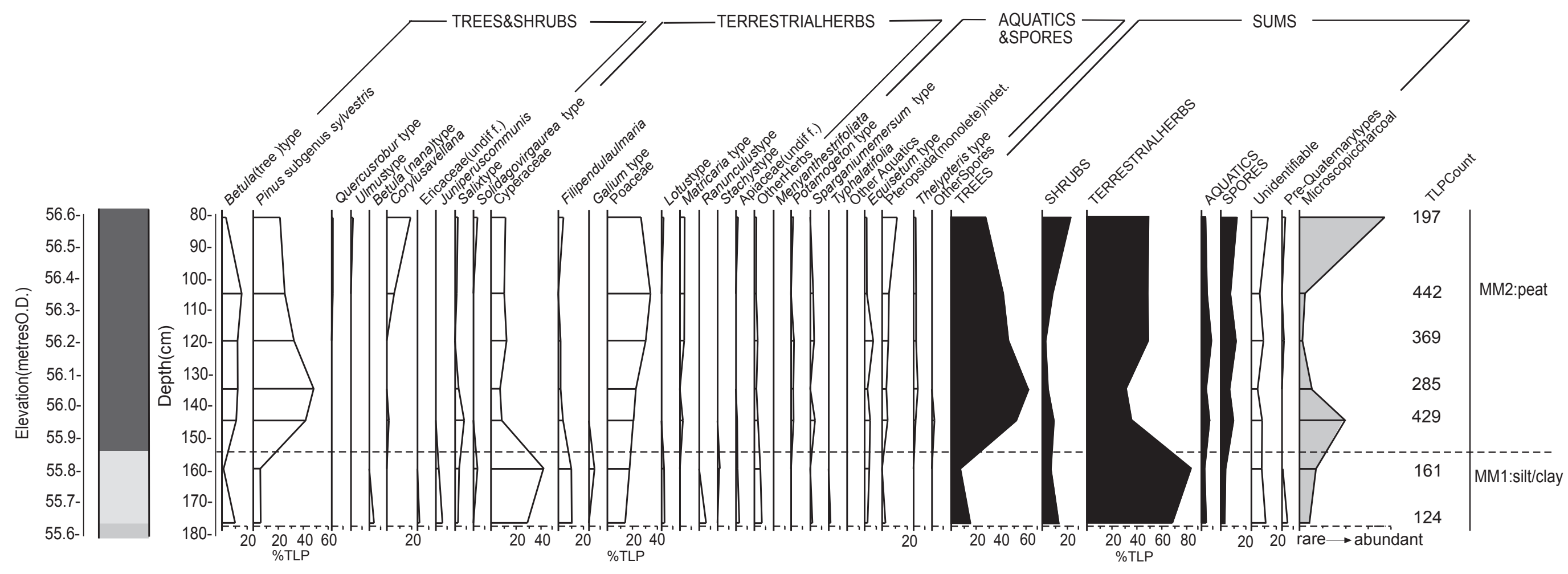




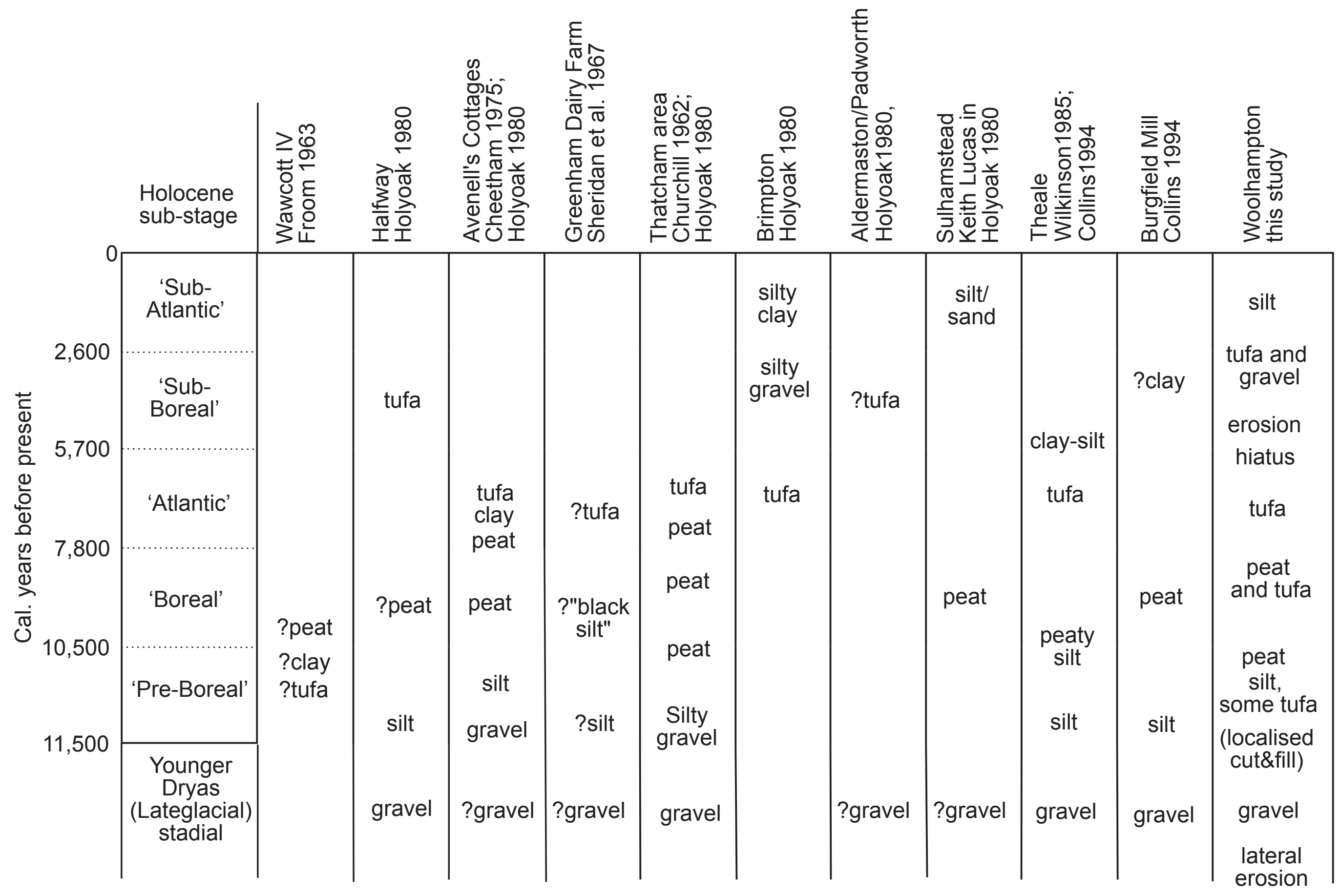


Sum cumulative

HLM2

HLM4

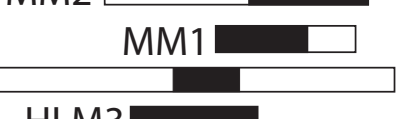

HLM3

20000CalBP

15000CaIBP

10000CaIBP

5000CalBP

Q652 9500ะ160BP

BM-1635R 9700+280BP

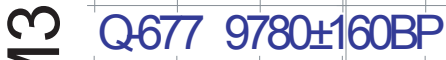

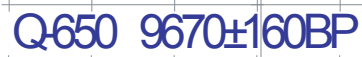

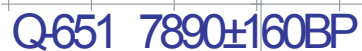

BM1459 9097 $\pm 69 B P$

BM-1634R 8300 $570 B P^{*}$

- - - - - -

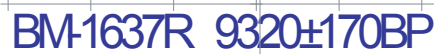

BM-1358 9280 $189 \mathrm{BP}$

Q659 10365 $\pm 170 \mathrm{BP}^{*}$

Q658 10030 $\pm 170 B P^{*}$

BM-1135 8928 \pm 71BP

BM-1136 9223 $\pm 100 B P$

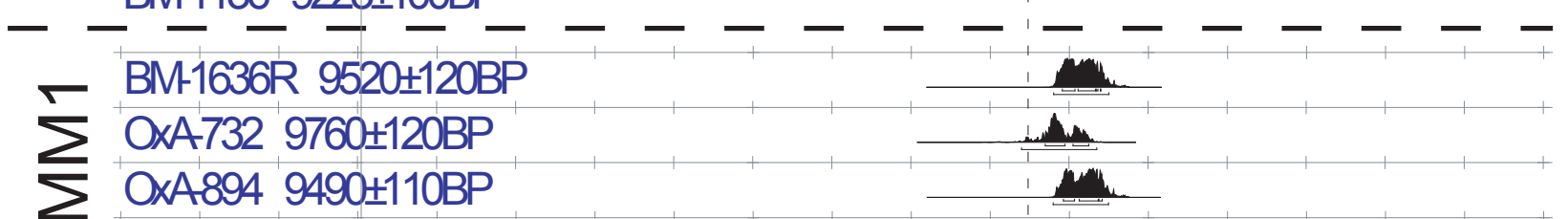

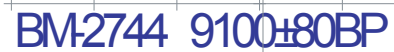

\begin{tabular}{l} 
\pm \\
$I$ \\
$I$ \\
\hline \\
$I$
\end{tabular}

BM-1460 10647 $\pm 900 B P^{*}$

BM-1402 9909 $\pm 75 \mathrm{BP}$

AA11974 9990+70BP

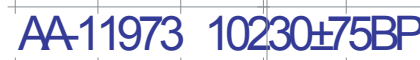

AA11977 9900 $\pm 100 B P$

AA11972 $11365 \pm \overline{0 B P}$

AA11976 11130+110BP

AA11969 11655+80BP

N SRR-4954 11505 $55 \mathrm{BP}$

$\sum$ AA11970 10790 $\pm 120 B P$

SRR-4508 13980 $\pm 145 B P *$

工 AA11975 11145 $\pm 75 \mathrm{BP}$

SRR-4509 11590 $445 B P$

AA11971 11280+85BP

SRR-4955 11725 $\pm 45 B P$

20000CalBP

15000CaIBP

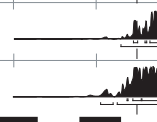

$+$

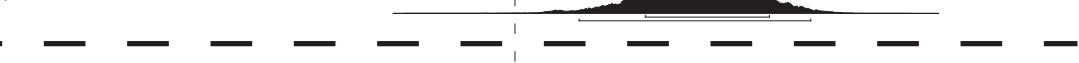

$1+1$ 


\begin{tabular}{|c|c|c|c|c|c|c|c|}
\hline Site & Reference & Lab code & $\begin{array}{l}\text { Mean } \\
{ }^{14} \mathrm{C} \text { date }\end{array}$ & $\begin{array}{l}\text { Calibrated date } \\
\text { (cal. BP) } 2 \text { s.d }\end{array}$ & Sample material & Environmental indicator & Sub-unit \\
\hline \multirow[t]{13}{*}{ Woolhampton } & $\begin{array}{c}\text { Collins et al. } \\
1996\end{array}$ & Beta 84057 & $9610 \pm 90$ & 11200BP- 10600BP & in situ Salix stump on peat & $\begin{array}{c}\text { Pollen - early interglacial } \\
\text { substage }\end{array}$ & MM2 \\
\hline & $"$ & AA 11974 & $9990 \pm 70$ & 11950BP-11200BP & $\begin{array}{l}\text { wood fragments in point } \\
\text { bar in gravel }\end{array}$ & $\begin{array}{c}\text { Pollen/plant macros -stadial/ } \\
\text { v. early interglacial }\end{array}$ & HLM4 \\
\hline & $"$ & AA11973 & $10230 \pm 75$ & 12650BP-11350BP & $\begin{array}{l}\text { plant detritus from top of } \\
\text { small channel }\end{array}$ & Pollen - stadial & HLM3 \\
\hline & $"$ & AA 11977 & $9900 \pm 100$ & 11950BP-11100BP & $\begin{array}{c}\text { plant detritus from base of } \\
\text { small channel }\end{array}$ & Pollen - stadial & HLM3 \\
\hline & $"$ & AA 11972 & $11365 \pm 90$ & 13800BP-13000BP & $\begin{array}{l}\text { plant detritus from top of } \\
\text { tilted channel }\end{array}$ & $\begin{array}{c}\text { Pollen - stadial } \\
\text { Mollusca - ?interstadial }\end{array}$ & HLM2 \\
\hline & $"$ & AA 11976 & $11130 \pm 110$ & 13450BP-12850BP & $\begin{array}{l}\text { plant detritus from base of } \\
\text { tilted channel }\end{array}$ & $\begin{array}{c}\text { Pollen - stadial } \\
\text { Mollusca - ?interstadial }\end{array}$ & HLM2 \\
\hline & $"$ & AA 11969 & $11655 \pm 80$ & 15050BP-13150BP & $\begin{array}{l}\text { plant detritus from large } \\
\text { channel }\end{array}$ & $\begin{array}{l}\text { Pollen, plant macros - } \\
\text { interstadial }\end{array}$ & HLM2 \\
\hline & $"$ & SRR 4954 & $11505 \pm 55$ & 13850BP-13150BP & $\begin{array}{c}\text { plant detritus from large } \\
\text { channel }\end{array}$ & $\begin{array}{l}\text { Pollen, plant macros - } \\
\text { interstadial }\end{array}$ & HLM2 \\
\hline & " & AA 11970 & $10790 \pm 120$ & 13150BP-12350BP & $\begin{array}{c}\text { plant detritus from large } \\
\text { channel }\end{array}$ & $\begin{array}{l}\text { Pollen, plant macros - } \\
\text { interstadial }\end{array}$ & HLM2 \\
\hline & $"$ & SRR 4508 & $13980 \pm 145$ & 17450BP-16150BP & $\begin{array}{l}\text { Plant detritus including } \\
\text { aquatics from large } \\
\text { channel }\end{array}$ & $\begin{array}{l}\text { Pollen, plant macros - } \\
\text { interstadial }\end{array}$ & HLM2 \\
\hline & $"$ & AA 11975 & $11145 \pm 75$ & 13450BP-12850BP & $\begin{array}{c}\text { plant detritus from large } \\
\text { channel }\end{array}$ & $\begin{array}{l}\text { Pollen, plant macros - } \\
\text { interstadial }\end{array}$ & HLM2 \\
\hline & $"$ & SRR 4509 & $11590 \pm 45$ & 13950BP-13150BP & $\begin{array}{c}\text { plant detritus from large } \\
\text { channel }\end{array}$ & $\begin{array}{l}\text { Pollen, plant macros - } \\
\text { interstadial }\end{array}$ & HLM2 \\
\hline & $"$ & AA 11971 & $11280 \pm 85$ & 13800BP-13000BP & $\begin{array}{c}\text { plant detritus from large } \\
\text { channel }\end{array}$ & $\begin{array}{c}\text { Pollen, plant macros - } \\
\text { interstadial }\end{array}$ & HLM2 \\
\hline
\end{tabular}




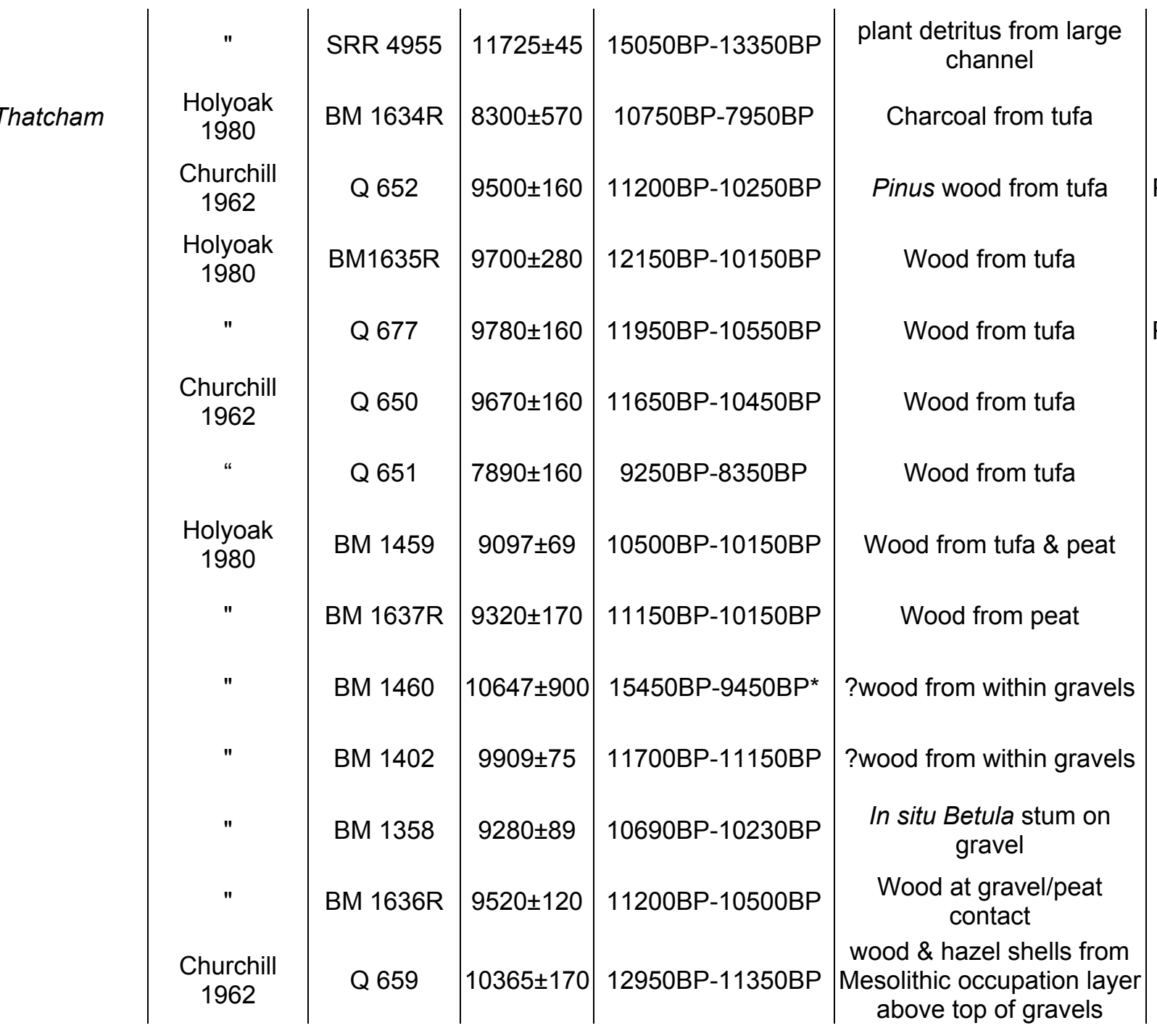

\begin{tabular}{c|c}
$\begin{array}{c}\text { Pollen, plant macros - } \\
\text { interstadial } \\
\begin{array}{c}\text { Pollen, mollusca - early } \\
\text { interglacial }\end{array}\end{array}$ & HLM2 \\
Pollen - early/mid interglacial & MM3 \\
Pollen - early interglacial & MM3 \\
Pollen - early/mid interglacial & MM3 \\
Pollen - early interglacial & MM3 \\
Pollen - early interglacial & MM3 \\
Pollen - early interglacial & MM3/4 \\
Pollen - early interglacial & MM2 \\
?stadial & ?HLM4 \\
?stadial & ?HLM4 \\
Early interglacial & MM1/2 \\
Stadial/early interglacial & MM2? \\
& MM1/2
\end{tabular}




\begin{tabular}{|c|c|c|c|c|c|c|c|}
\hline & " & Q 658 & $10030 \pm 170$ & 12650BP-11050BP & \begin{tabular}{|} 
wood \& hazel shells from \\
Mesolithic occupation layer
\end{tabular} & Early interglacial & MM1/2 \\
\hline & Jacobi 1987 & OxA-732 & $9760 \pm 120$ & 11600BP-10650BP & $\begin{array}{c}\text { antler on gravel/ in humic } \\
\text { silt }\end{array}$ & Stadial/interglacial & $\begin{array}{l}\text { HLM3/4 or } \\
\text { MM1? }\end{array}$ \\
\hline & " & OxA-894 & $9490 \pm 110$ & 11200BP-10500BP & $\begin{array}{c}\text { elk antler on gravel/ in } \\
\text { humic silt }\end{array}$ & Stadial/interglacial & $\begin{array}{l}\text { HLM3/4 or } \\
\text { MM1? }\end{array}$ \\
\hline & $\begin{array}{l}\text { Healy et al. } \\
1992\end{array}$ & BM2744 & $9100 \pm 80$ & 10500BP-9900BP & $\begin{array}{c}\text { charred hazlenuts in silts } \\
\text { above gravel, associated } \\
\text { with Mesolithic 'home } \\
\text { base' }\end{array}$ & Early interglacial & MM1 \\
\hline \multirow[t]{2}{*}{$\begin{array}{l}\text { Avenell's } \\
\text { Cottages }\end{array}$} & $\begin{array}{l}\text { Cheetham } \\
1975\end{array}$ & BM 1135 & $8928 \pm 71$ & 10230BP-9770BP & Salix wood in peat & Pollen - early/mid interglacial & MM1 \\
\hline & $"$ & BM 1136 & $9223 \pm 100$ & 10680BP-10210BP & wood in peaty clay & early interglacial pollen & MM1/2 \\
\hline
\end{tabular}




\begin{tabular}{|c|c|c|c|c|c|c|c|c|c|c|}
\hline & $\mathrm{C} 1$ & $\mathrm{C} 2$ & $\mathrm{C} 3$ & $\mathrm{C} 4$ & $\mathrm{C} 5$ & C6 & $\mathrm{C} 7$ & $\mathrm{C} 8$ & $\mathrm{~T} 1$ & $\mathrm{~T} 2$ \\
\hline Betula undiff. & 6.7 & 76.5 & 8.3 & 7.5 & 6.1 & 24.8 & 1.1 & 6.9 & 55.0 & 41.9 \\
\hline $\begin{array}{l}\text { Pinus subgenus } \\
\text { Pinus }\end{array}$ & - & 5.9 & 6.7 & 1.6 & 2.4 & 3.1 & 1.1 & 10.3 & 6.8 & 1.2 \\
\hline Tilia cordata & - & - & - & - & - & - & 1.1 & - & - & - \\
\hline Alnus glutinosa & - & - & - & - & - & - & 1.1 & - & - & 0.2 \\
\hline $\begin{array}{l}\text { Corylus avellana } \\
\text { type }\end{array}$ & - & - & 5.0 & 0.6 & - & - & 3.4 & - & - & - \\
\hline Salix undiff. & - & - & 11.7 & 1.3 & - & - & - & 6.9 & 11.8 & 9.1 \\
\hline $\begin{array}{l}\text { Juniperus } \\
\text { communis }\end{array}$ & - & - & 3.3 & 1.3 & 1.2 & - & - & . & - & 0.2 \\
\hline Poaceae & 20.0 & 5.9 & 30.0 & 28.8 & 24.4 & 40.3 & 14.8 & 41.4 & 10.7 & 13.4 \\
\hline Cyperaceae & 20.0 & 11.8 & 18.3 & 17.6 & 34.1 & 9.3 & 4.5 & 6.9 & 4.7 & 12.5 \\
\hline Sagina type & - & - & - & - & - & 0.8 & - & - & - & - \\
\hline $\begin{array}{l}\text { Silene dioica } \\
\text { type }\end{array}$ & - & - & - & - & - & - & - & - & - & 0.2 \\
\hline Chenopodiceae & - & - & 1.7 & - & - & - & - & - & - & - \\
\hline Lactucae undiff. & 20.0 & - & - & - & 4.9 & 0.8 & 40.9 & 20.7 & 0.2 & 0.2 \\
\hline $\begin{array}{l}\text { Artemisia } \\
\text { vulgaris type }\end{array}$ & - & - & 1.7 & 1.9 & 2.4 & 3.9 & - & - & 0.9 & 1.8 \\
\hline Aster type & - & - & 1.7 & 1.3 & 1.2 & 0.8 & 14.8 & - & 0.2 & 0.5 \\
\hline Centaurea type & - & - & - & - & 1.2 & - & - & - & - & - \\
\hline Cirsium type & - & - & - & - & - & - & - & - & 0.2 & - \\
\hline Matricaria type & - & - & - & 1.3 & 2.4 & - & - & - & 0.2 & 0.5 \\
\hline Anthemis type & - & - & - & - & - & - & 3.4 & - & - & - \\
\hline Cruciferae undiff. & - & - & - & 0.6 & - & - & - & - & - & - \\
\hline Sinapis type & - & - & - & 1.9 & 1.2 & - & - & - & - & - \\
\hline Hornungia type & - & - & 1.7 & - & 2.4 & - & - & - & - & 1.1 \\
\hline $\begin{array}{l}\text { Stachys } \\
\text { sylvatica type }\end{array}$ & - & - & - & 1.3 & 2.4 & - & - & - & 0.2 & 0.7 \\
\hline Lamium type & - & - & 1.7 & - & - & - & - & - & - & - \\
\hline $\begin{array}{l}\text { Leguminosae } \\
\text { undiff. }\end{array}$ & - & - & - & 0.6 & - & - & - & - & - & - \\
\hline $\begin{array}{l}\text { Lotus } \\
\text { uligonosum type }\end{array}$ & 6.7 & - & 1.7 & 2.5 & 1.2 & - & 1.1 & - & 0.7 & 2.5 \\
\hline Cornus suecica & - & - & 1.7 & - & 1.2 & - & - & - & - & - \\
\hline $\begin{array}{l}\text { Cornus } \\
\text { sanguinea }\end{array}$ & - & - & - & - & - & - & - & - & 0.2 & - \\
\hline $\begin{array}{l}\text { Polygonum } \\
\text { aviculare type }\end{array}$ & - & - & - & - & - & - & 2.3 & - & - & - \\
\hline Ranunculus type & - & - & - & - & - & - & - & - & - & 0.9 \\
\hline $\begin{array}{l}\text { Caltha palustris } \\
\text { type }\end{array}$ & - & - & - & - & - & 0.8 & 1.1 & - & 0.7 & - \\
\hline Thalictrum type & - & - & - & 0.6 & - & 2.3 & - & - & 0.2 & - \\
\hline Rosaceae undiff. & 13.3 & - & - & - & - & - & - & - & 0.2 & - \\
\hline Dryas octapetala & - & - & - & 2.5 & 1.2 & 0.8 & - & - & 0.7 & 0.2 \\
\hline $\begin{array}{l}\text { Filipendula } \\
\text { ulmaria }\end{array}$ & 13.3 & - & 1.7 & 20.1 & 8.5 & 6.2 & 9.1 & 6.9 & 6.1 & 9.1 \\
\hline $\begin{array}{l}\text { Sanguisorba } \\
\text { officianalis }\end{array}$ & - & - & - & - & - & - & - & - & - & 0.2 \\
\hline Potentilla type & - & - & - & 1.3 & 1.2 & - & - & - & - & 0.2 \\
\hline
\end{tabular}




\begin{tabular}{|c|c|c|c|c|c|c|c|c|c|c|}
\hline Rubiaceae & - & - & 1.7 & - & - & - & - & - & - & - \\
\hline Galium type & - & - & - & 0.6 & - & 1.6 & - & - & 0.2 & 0.2 \\
\hline $\begin{array}{l}\text { Rumex } \\
\text { acetosella type }\end{array}$ & - & - & - & - & - & - & - & - & - & 0.9 \\
\hline Oxyria type & - & - & - & - & - & 1.6 & - & - & - & 0.2 \\
\hline Rhinanthus type & - & - & 1.7 & - & - & - & - & - & - & - \\
\hline Apiaceae undiff. & - & - & - & 5.0 & - & 1.6 & - & - & 0.4 & 1.8 \\
\hline Urtica dioica & - & - & - & - & - & 1.6 & - & - & - & 0.2 \\
\hline $\begin{array}{l}\text { Total Land } \\
\text { Pollen }\end{array}$ & 15.0 & 17.0 & 60.0 & 159.5 & 82.0 & 129.0 & 88.0 & 14.5 & 569.5 & 441.5 \\
\hline $\begin{array}{l}\text { Lythrum portula } \\
\text { type }\end{array}$ & - & - & 1.6 & - & - & - & - & 6.1 & 0.2 & - \\
\hline $\begin{array}{l}\text { Menyanthes } \\
\text { trifoliata }\end{array}$ & - & - & - & - & - & 0.8 & - & - & - & - \\
\hline $\begin{array}{l}\text { Myriophyllum } \\
\text { spicatum }\end{array}$ & - & - & - & - & - & - & - & - & 0.2 & - \\
\hline $\begin{array}{l}\text { Potamogetonace } \\
\text { ae }\end{array}$ & - & - & - & 1.2 & - & - & - & 6.1 & - & - \\
\hline $\begin{array}{l}\text { Sparganium } \\
\text { emersum type }\end{array}$ & - & 5.6 & - & - & - & - & - & - & 0.3 & 3.1 \\
\hline $\begin{array}{l}\text { Total } \\
\text { semi/aquatics }\end{array}$ & - & 5.6 & 1.6 & 1.2 & - & 0.8 & - & 12.1 & 0.7 & 3.1 \\
\hline $\begin{array}{l}\text { Blechnum } \\
\text { spicant }\end{array}$ & - & - & - & - & - & - & - & - & 0.2 & - \\
\hline Dryopteris type & - & - & - & - & - & 0.8 & - & - & 0.5 & - \\
\hline Lycopodium type & - & - & - & - & - & 0.8 & - & - & - & - \\
\hline $\begin{array}{l}\text { Polypodium } \\
\text { vulgare }\end{array}$ & - & - & - & 0.6 & - & - & - & - & - & - \\
\hline Equisetum type & - & 5.3 & - & - & 1.2 & - & - & - & - & - \\
\hline $\begin{array}{l}\text { Pteropsida } \\
\text { (monolete) } \\
\text { undiff. }\end{array}$ & 21.1 & - & - & 0.6 & 3.5 & - & - & - & 0.5 & 0.7 \\
\hline Sphagnum & - & - & - & - & - & - & - & - & - & 0.2 \\
\hline Total spores & 21.1 & 5.3 & - & 1.2 & 4.7 & 1.5 & - & - & 1.2 & 0.9 \\
\hline $\begin{array}{l}\text { Pre-Quaternary } \\
\text { taxa }\end{array}$ & 14.3 & - & 11.5 & 12.4 & 4.0 & 2.8 & 3.3 & 17.8 & 0.5 & 0.4 \\
\hline Unidentifiable & 17.9 & 24.0 & 10.3 & 15.5 & 9.1 & 4.2 & - & 8.9 & 0.5 & 7.6 \\
\hline $\begin{array}{l}\text { Total pollen } \\
\text { and spores }\end{array}$ & 28.0 & 25.0 & 78.0 & 226.5 & 99.0 & 142.0 & 91.0 & 22.5 & 586.5 & 499.5 \\
\hline $\begin{array}{l}\text { Number of } \\
\text { Quaternary taxa }\end{array}$ & 8.0 & 6.0 & 18.0 & 24.0 & 20.0 & 19.0 & 14.0 & 9.0 & 26.0 & 28.0 \\
\hline $\begin{array}{l}\text { Diversity (TLP } \\
\text { taxa/ TLP count) }\end{array}$ & 0.5 & 0.2 & 0.3 & 0.1 & 0.2 & 0.1 & 0.2 & 0.5 & - & 0.1 \\
\hline
\end{tabular}




\begin{tabular}{ccccc} 
MM2 & MM3 & MM4 & MM4 & MM6 \\
$128-126 \mathrm{~cm}$ & $110-105 \mathrm{~cm}$ & $70-65 \mathrm{~cm}$ & $53-47 \mathrm{~cm}$ & $15-10 \mathrm{~cm}$ \\
\hline
\end{tabular}

TERRESTRIAL

Aegopinella sp.

$\begin{array}{lcccc}- & - & - & 4 & - \\ - & 3 & 2 & 1 & 9 \\ - & 9 & - & 2 & - \\ - & - & - & 2 & - \\ - & 28 & - & 4 & - \\ - & - & - & 1 & - \\ - & - & 1 & 1 & - \\ - & 2 & - & 2 & - \\ - & - & - & - & 1 \\ - & 1 & 1 & 10 & 1 \\ - & - & - & - & 3 \\ - & 17 & 1 & - & 1 \\ - & 1 & - & - & - \\ 0 & 61 & 5 & 27 & 15\end{array}$

\section{Aegopinella cf. nitidula}

Aegopinella cf. pura

Carychium cf. minimum

Carychium cf. tridentatum

Cecilioides acicula

Cochlicopa lubrica/lubricella

Pupilla muscorum

Succinea sp.

Succinea cf. putris

Vallonia costata

Vallonia pulchella

Vertigo cf. antivertigo

TOTAL TERRESTRIAL

$\begin{array}{ccccc}- & 3 & - & - & - \\ - & - & - & 14 & - \\ 1 & 8 & - & - & - \\ - & 14 & - & - & - \\ - & 29 & - & - & - \\ - & 41 & 1 & - & - \\ - & 4 & - & - & - \\ - & - & - & 1 & - \\ - & - & 4 & - & - \\ 1 & 99 & 5 & 15 & 0\end{array}$

AQUATIC

Bithynia tentaculata

Lymnaea cf. truncatula

Pisidium sp.

Pisidium cf. amnicum

Planorbis sp. (juvenile)

Planorbis contortus

Planorbis planorbis

Planorbis leucostoma

Valvata piscinalis

TOTAL AQUATIC

160

$10 \quad 42$ 